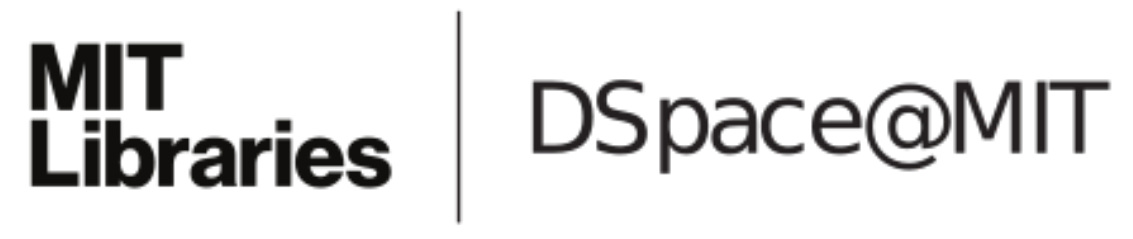

\author{
MIT Open Access Articles \\ Disclosure incentives when competing \\ firms have common ownership
}

The MIT Faculty has made this article openly available. Please share how this access benefits you. Your story matters.

As Published: 10.1016/J.JACCEC0.2019.02.001

Publisher: Elsevier BV

Persistent URL: https://hdl.handle.net/1721.1/136172

Version: Author's final manuscript: final author's manuscript post peer review, without publisher's formatting or copy editing

Terms of use: Creative Commons Attribution-NonCommercial-NoDerivs License 


\title{
Disclosure incentives when competing firms have common ownership
}

\author{
Jihwon Park \\ Harvard Business School \\ jpark@hbs.edu \\ Jalal Sani \\ Penn State University \\ sani@psu.edu \\ Nemit Shroff \\ Massachusetts Institute of Technology \\ shroff@mit.edu \\ Hal White \\ Penn State University \\ hdw113@psu.edu
}

Journal of Accounting \& Economics, forthcoming

\begin{abstract}
This paper examines whether common ownership - i.e., instances where investors simultaneously own significant stakes in competing firms - affects voluntary disclosure. We argue that common ownership (i) reduces proprietary cost concerns of disclosure, and (ii) incentivizes firms to "internalize" the externality benefits of their disclosure for co-owned peer firms. Accordingly, we find a positive relation between common ownership and disclosure. Evidence from cross-sectional tests and a quasi-natural experiment based on financial institution mergers help mitigate concerns that our results are explained by an omitted variable bias or reverse causality. Finally, we find that common ownership is associated with increased market liquidity.
\end{abstract}

This paper integrates two working papers "Common Institutional Blockholdings and Voluntary Disclosure" by Sani and White, and "Common Ownership and Disclosure Incentives" by Park and Shroff. We thank Matt Bloomfield (the reviewer), Wayne Guay (the editor), Karthik Balakrishnan, Dan Givoly, Jeremiah Green, David Haushalter, Karl Muller, Jed Neilson, Martin Nienhaus, Jordan Schoenfeld, and workshop and conference participants at Cornell University, Frankfurt School of Finance \& Management, MIT, Penn State University, University of Buffalo, University of Mannheim and University of Minnesota Empirical Conference for many helpful comments and suggestions. Park gratefully acknowledges financial support from Samsung Scholarship. All errors are our own. 


\section{Introduction}

The share of public U.S. firm stock owned by large institutional investors has substantially increased, and become more concentrated, over the past three decades. As a result, competing firms are increasingly becoming owned, in part, by the same large institutions (henceforth, common ownership). Theory suggests that when investors have (partial) equity ownership in competing firms, these firms have (i) less incentive to compete than they would if each firm had separate owners without a financial interest in the firms' competitors and (ii) greater incentive to consider the benefits of their actions for commonly-owned peer firms (Hansen and Lott, 1996; Rubin, 2006; Azar, 2017). The intuition is twofold. First, as firms compete aggressively, they engage in behaviors (e.g., patent races, price under-cutting) to gain an advantage relative to other firms, but the collective effect of these actions can negatively impact the common owners' total portfolio value (i.e., lower combined profits across firms). Thus, common ownership can reduce firms' incentives to compete. Second, if a firm's actions have positive externalities on other firms, common ownership creates incentives for the firm to internalize these externalities in a manner that increases the portfolio value of the common owner. Consistent with this intuition, recent studies find evidence supporting the anticompetitive effects of common ownership (Azar et al., 2016, 2018; He and Huang, 2017) and evidence that common ownership leads firms to internalize externalities (He et al., 2018a).

In this paper, we examine whether common ownership increases firms' incentives to disclose. Our analysis is motivated by two arguments. First, the research mentioned above suggests that managers of co-owned firms recognize the anti-competitive incentives of common owners and behave in ways to increase the portfolio value of the common owners. To the extent these coowned firms are less competitive with each other, we argue they are likely to be less concerned that proprietary information conveyed in their disclosures will be used by competitors to gain market share/profits at the expense of the disclosing firm. Considering that proprietary cost is one 
of the primary constraints to full disclosure by firms, by relaxing that constraint, common ownership can lead to more disclosure.

Second, aside from a potential reduction in the proprietary cost of disclosure, there is also a potential increase in the benefit of disclosure from common ownership. In particular, prior research provides theoretical and empirical evidence that greater disclosure by one firm in an industry can have spillover effects related to liquidity and cost of capital for other firms in that industry (Admati and Pfleiderer, 2000; Bushee and Leuz, 2005; Shroff et al., 2017). We argue that common ownership creates incentives for firms to internalize these positive externalities, thereby increasing disclosure. That is, increased disclosure by one co-owned firm can increase the portfolio value of common owners not only through improved liquidity and lower cost of capital of the disclosing firm (direct benefit), but also through improved liquidity and lower cost of capital of other same-industry firms in the common owner's portfolio (indirect benefit). Based on the above two arguments, we predict that common ownership increases firms' incentives to disclose.

Nevertheless, there are at least three reasons why common ownership might not lead to increased disclosure. First, although co-owned firms might face reduced competition from one another, it's unclear to what extent common ownership would result in greater disclosure because these firms still face nontrivial proprietary costs from non-co-owned firms (e.g., private firms) as well as other disclosure costs that may still bind the firm. Second, prior research suggests that institutional investors with large positions in a firm can execute profitable trades based on their private information, especially in opaque information environments (e.g., Bushee and Goodman, 2007; Maffett, 2012). Specifically, an opaque disclosure environment creates incentives for investors to become privately informed (Verrecchia, 1982; Diamond, 1985), and institutional investors have greater ability to acquire and execute profitable trades based on private information (Maffett, 2012). As a result, increased disclosure could reduce the ability of common owners, typically large institutions, to execute profitable trades based on their private information. Finally, 
the theoretical literature offers conflicting predictions on whether competition increases or decreases disclosure incentives (see e.g., Verrecchia, 1983, 1990; Darrough and Stoughton, 1990; Darrough, 1993), and empirical studies find mixed evidence on the association between proxies for competition and disclosure (see Beyer et al. (2010) for a review). ${ }^{1}$ Thus, it is ex ante unclear how common ownership affects disclosure incentives.

To conduct our analyses, we define firm-year observations as having a common owner if an investor owns at least five percent equity in two or more firms in an industry (defined based on the Hoberg and Phillips $(2010,2016) 300$-industry classification). We focus on investors with at least five percent ownership (henceforth, blockholders) because such investors have several mechanisms to influence corporate decisions, including disclosure. In particular, prior research suggests that blockholders can influence managers through private communications, board member elections, and shareholders proposals (e.g., Del Guercio and Hawkins, 1999; McCahery et al., 2016). In addition to the direct mechanisms, blockholders that aren't required to hold shares (e.g., active investors) can influence firm decisions indirectly via threat of selling, i.e., exiting, the firm (e.g., Edmans and Manso, 2011; Bharath et al., 2013).

Our disclosure proxies are based on the intuition that common ownership results in both a decrease in the cost of proprietary disclosure and an increase in the benefit of disclosure due to externalities to co-owned peer firms. We use three disclosure proxies that are all useful to the market (i.e., generate externalities), but differ in the degree to which they reveal proprietary information: (i) earnings forecasts, (ii) capital expenditure (capex) forecasts, and (iii) redacted disclosures. Earnings forecasts are arguably the least 'costly' means to disclose more information without harm from competitors, because they aggregate information rather than reveal the granular level of detail that is most useful to competitors (Lang and Sul, 2014; Glaeser, 2018). Moreover,

\footnotetext{
${ }^{1}$ That said, recent evidence based on different quasi-natural experiments consistently finds that competition increases proprietary cost concerns and reduces disclosure (Bernard, 2016; Huang et al., 2017; Li et al., 2017; Aobdia, 2018; Bernard et al., 2018). Further, surveys of managers suggest that competitive concerns deter, rather than promote, their disclosure (Graham et al., 2005; Dedman and Lennox, 2009; Minnis and Shroff, 2017).
} 
because these forecasts are a function of the manager's beliefs about how earnings will be impacted by the firm's actions as well as external economic factors (Goodman et al., 2014), it is difficult for competitors to infer the firm's actions from the forecasts. Yet, prior research finds evidence that these forecasts are useful in that they help increase liquidity and lower the cost of capital for the disclosing firm (Coller and Yohn, 1997; Shroff et al., 2013; Balakrishnan et al., 2014) as well as its peers (Baginski and Hinson, 2016).

Our second proxy, capex forecasts, provides more proprietary information, as these forecasts represent expected future cash outlays by the firm (Li, 2010; Lu and Tucker, 2012). As such, a capex forecast can be considered a direct input-based proxy. Given the granularity of the information in a capex forecast regarding the firm's production function and relatively longer payoff horizon, these forecasts can impose greater proprietary costs on the disclosing firm. Finally, we use redacted disclosures (approved by the SEC via confidential treatment orders (CTOs)) to capture the most direct, granular release of proprietary information (Verrecchia and Weber, 2006; Boone et al., 2016). CTO redactions are well-suited to capture proprietary information, as CTO requests are granted by the SEC if the firm can demonstrate that such disclosure could adversely affect its profits via competitive harm-i.e., there are actual proprietary costs. ${ }^{2}$

Note that while our main argument is that three types of disclosure vary in the degree to which they reveal proprietary information, the externalities they confer upon peer firms could also differ. In particular, it is plausible that forecasts contain more systemic information (e.g., industryrelated information) relative to the information in material contracts, which could be more idiosyncratic to the firm and its immediate competitors. Thus, the externality value of forecasts could be greater than that of CTO redactions.

We test our predictions using a sample of $54,541(66,455)$ U.S. public firm-year observations from 1999 to 2015 (1997 to 2015) when the disclosure proxy is management forecasts

\footnotetext{
${ }^{2}$ The CTO allows confidential treatment of information in material contracts that would have otherwise been required to be filed with the SEC. These material contracts include, but are not limited to, royalty agreements, joint ventures, research and development, patents, and employee contracts (Verrecchia and Weber, 2006).
} 
(redactions). Consistent with our prediction, we find that common ownership is positively associated with the likelihood and frequency of issuing earnings and capex forecasts. These results are robust to the inclusion of firm and industry-year fixed effects, blockholder fixed effects, several time-varying control variables (including investors' common ownership in non-competing firms - i.e., firms operating in other industries), several proxies for the degree of common ownership interest in competing firms, and different industry classification approaches (such as SIC 4-digit and NAICS 4-digit). Our coefficient estimates imply that firms that have common owners are $9.5 \%$ $(22 \%)$ more likely to issue an earnings (capex) forecast and issue $8.8 \%(12.9 \%)$ more earnings (capex) forecasts on average than firms that do not have a common owner.

We also find common ownership is not significantly associated with redactions (our most direct, granular proxy for proprietary information), consistent with co-owned firms not fully disclosing all information. This lack of disclosure could be due to managers' concern of remaining competition from non-commonly owned firms; however, it is also possible, as we note earlier, that the lack of disclosure could result from managers believing that CTOs have less systemic information, and therefore provide less of an externality benefit, despite containing more proprietary information. It is also important to note that contractual counterparties could feasibly demand that firms refrain from disclosing details about the contract. Thus, it is difficult to infer the managerial intent behind the non-disclosure.

A potential concern with the preceding analyses is that unobservable variables (e.g., performance expectations) may be correlated with both disclosure policy and common ownership (even though we include an extensive set of control variables and fixed-effects). As an alternative approach, we use financial institution mergers to generate exogenous variation in common ownership (He and Huang, 2017; Azar et al., 2018). As we discuss in more detail in section 5, this approach allows us to identify plausibly exogenous increases in common ownership for some firms while leaving other (similar) firms to serve as the control group. ${ }^{3}$ Using a difference-in-differences

\footnotetext{
${ }^{3}$ Nevertheless, this setting has some important limitations, which we discuss in section 5 .
} 
estimator, we find that treated firms are significantly more likely to issue earnings and capex forecasts and provide more frequent capex forecasts relative to control firms after exogenous increases in common ownership. Consistent with our main results, we find no significant association between changes in common ownership and redactions.

We conduct two additional tests to shed light on the reason why common ownership increases disclosure. First, we test and find that the relation between common ownership and disclosure is greater when the proportion of firms in the industry that are commonly owned is higher, consistent with greater perceived disclosure benefits as a result of reduced proprietary costs. Second, to isolate the externality channel, we examine whether firms increase disclosure in response to their co-owned peer firms' demand for additional public information. Specifically, we examine whether firms increase disclosure in response to a temporary (and exogenous) loss of public information related to co-owned peer firms when these peer firms lose analyst coverage due to a broker closure/merger (Kelly and Ljungqvist, 2012). Prior research suggests that a loss of analyst coverage increases information asymmetry for that firm, and thus firms experiencing losses in analyst coverage respond by increasing voluntary disclosure. If common ownership incentivizes firms to consider the benefits of their disclosures for co-owned peers, then a loss in analyst coverage for one co-owned firm increases the externality benefit of the disclosures of its co-owned peer firms. Consistent with this argument, we find evidence that exogenous losses in analyst coverage for one firm leads to an increase in disclosure by it co-owned peers.

Finally, we examine whether common ownership is associated with an increase in stock liquidity, as common owners are typically large institutions, which greatly value liquidity due to the size and frequency of their trading. ${ }^{4}$ If common ownership results in an increase in disclosure, then we should find that these additional disclosures result in increased stock liquidity (e.g., Diamond and Verrecchia, 1991). Consistent with our expectation, we find that common ownership

\footnotetext{
${ }^{4}$ Note that even passive long-term investors value liquidity, as they frequently rebalance their portfolios and incur higher trading costs when the stock is illiquid.
} 
is associated with lower bid-ask spread and higher liquidity, measured using Amihud (2002) approach. Our coefficients suggest that firms with common owners have approximately $2.5 \%$ lower spreads and $2.4 \%$ higher liquidity relative to firms without common owners.

Our evidence is important because consolidation in the asset management industry and the substantial rise in mutual fund investing have led to a small number of institutional investors becoming the largest shareholders of most publicly traded firms in the U.S. and in other developed economies. For example, our data reveal that as of December 2015, BlackRock and Vanguard are among the largest five shareholders of more than $53 \%$ of firms in the universe of Compustat firms (see Table 3; Anton et al. (2018) report similar evidence). Given the pervasiveness of common ownership as a feature of the new economy, it is important to understand the consequences of common ownership on firm behavior. Our paper takes a step in this direction by showing the effect of common ownership on disclosure incentives.

This study contributes to two strands of literature. First, our paper contributes to a growing literature examining the economic implications of common ownership. ${ }^{5}$ Specifically, our study (along with Pawliczek and Skinner (2018), discussed below) is the first to examine the effect of common ownership on disclosure incentives and liquidity. Second, this paper is related to the literature examining the relation between institutional ownership and disclosure. ${ }^{6}$ Much of the literature treats each firm as an independent holding of the institutional investor; Jung (2013) being an exception. Jung (2013) finds that institutional investor overlap leads to a diffusion of disclosures practices, which leads firms with common investors to have more similar disclosure practices. Our findings build on this literature by showing that institutional owners that are blockholders of related firms can further affect disclosure incentives by reducing proprietary cost concerns and increasing externality benefits.

\footnotetext{
${ }^{5}$ See e.g., Liang (2016), Azar et al. (2016, 2018), He and Huang (2017), Kang et al. (2018), Anton et al. (2018).

${ }^{6}$ See e.g., Lang and Lundholm (1996), Bushee and Noe (2000), Ajinkya et al. (2005), Maffett (2012), Jung (2013), Boone and White (2015), Bourveau and Schoenfeld (2017), Schoenfeld (2017) and Abramova et al. (2018).
} 
Finally, a concurrent working paper, Pawliczek and Skinner (2018; henceforth PS), also examines the relation between common ownership and disclosure. Our papers differ along four dimensions. First, we propose and provide evidence that common ownership can also affect disclosure incentives through externalities. Second, we examine three forms of disclosure that vary in the degree to which they reveal proprietary information exploitable by competitors. The examination of different types of disclosure helps enhance our understanding the degree to which common ownership relaxes proprietary cost concerns of disclosure. Third, we document that common ownership results in increased liquidity. Finally, our empirical design differs from that in PS along two important dimensions: (i) the proxy for common ownership, and (ii) the fixed effects structure. Thus, the evidence using the two approaches is complementary in nature and helps reinforce the inferences of both papers.

\section{Literature review and hypothesis}

\subsection{Prior research on common ownership}

A large theoretical literature shows that partial common ownership of firms creates incentives for firms to consider, or internalize, the consequences of their actions on the value of other firms in the common owners' portfolio. ${ }^{7}$ As a result, common ownership reduces firms' incentives to compete compared to a situation in which each firm has distinct owners that do not have a financial interest in competitors. The intuition underlying these theories is straightforward: the benefit of competing aggressively - gains in market share - comes at the expense of firms in the same industry, and reduces industry profits. A common owner that holds equal shares in all firms in an industry therefore does not benefit from aggressive competition such as price undercutting, advertising wars, and patent races. Thus, as common ownership increases, fewer owners support an aggressive competitive strategy.

\footnotetext{
${ }^{7}$ See Rotemberg (1984), Gordon (1990), Hansen and Lott (1996), O’Brien and Salop (2000), Gilo et al. (2006), Rubin (2006), and Azar (2017).
} 
Several recent studies provide empirical support for this theoretical prediction. Azar et al. (2018) study the effect of common ownership on ticket prices in the U.S. airline industry and find that increases in common ownership at the airline-route level leads to a 3-7\% increase in ticket prices in these routes. Studying the U.S. banking sector, Azar et al. (2016) document that common ownership increases prices of deposit products, such as maintenance fees, and decreases deposit interest rates. Panayides and Thomas (2017) study a broad sample of industries and find that common ownership leads to decreased competition for market share and increased profitability. Gutiérrez and Philippon (2017) show that common ownership is negatively associated with firms' tendency to invest despite high profit and Tobin's q. He et al. (2018a and 2018b) find that common ownership leads firms to internalize the consequences of their governance choices on other firms. ${ }^{8}$

To better appreciate the source of the growth of common ownership over time, Anton et al. (2018) provide descriptive evidence that large mutual fund companies have grown significantly in the last two decades, thereby becoming common owners for a large percentage of firms. Specifically, the growth in mutual fund common ownership is attributed to (i) the significant rise in mutual fund investing and (ii) consolidation in the asset management industry. Consistent with the above points, we find that BlackRock and Vanguard are among the largest five shareholders of more than $53 \%$ of all publicly traded firms in the Compustat universe in 2015. In contrast, these two institutions were among the top-five shareholders in fewer than five percent of Compustat universe in 1997 (see Table 3). Other examples of growth in large institutional common ownership include State Street and T. Rowe Price.

\footnotetext{
${ }^{8}$ The potential anti-competitive implications of common ownership have concerned even antitrust scholars (See Elhauge (2017) for a review of related literature in Law) and antitrust enforcers. For instance, the Assistant Attorney General for the Antitrust Division of the Department of Justice informed a Senate subcommittee that it is exploring common ownership "in more than one industry" (https:/www.judiciary.senate.gov/meetings/oversight-of-theenforcement-of-the-antitrust-laws-2016). The Federal Trade Commission recently challenged a merger based on anticompetitive concerns related to common ownership (https://www.shearman.com/perspectives/2017/\%2011/ftcchallenge-of-red-ventures-bankrate). A case study by Martin Schmalz provides anecdotal evidence for anticompetitive effects of common ownership: http://ericposner.com/martin-schmalz-how-passive-funds-preventcompetition/.
} 


\subsection{Hypothesis}

We argue there are two mechanisms through which common ownership affects firms' disclosure incentives: (i) reduction in proprietary costs, and (ii) internalization of disclosure externalities. The first argument is that if common ownership creates anticompetitive incentives, firms should be less concerned about disclosing proprietary information. Given investor demand for more complete disclosure, along with relaxed concerns of proprietary costs, firms with common owners should increase their disclosure. The second argument is based on the disclosure externality literature, which argues that the disclosures of one firm can improve the information environment for other firms within the industry by reducing uncertainty about demand, supply and cost conditions, as these factors are interrelated within an industry. ${ }^{9}$ Specifically, Dye (1990) and Admati and Pfleiderer (2000) develop analytical models that show disclosures of one firm lead to positive externalities in the form of liquidity spillovers for related firms; Bushee and Leuz (2005), Baginski and Hinson (2016) and Shroff et al. (2017) provide empirical evidence of such externalities. In the presence of such externalities, investors that have an ownership interest in several firms in the industry derive both (i) the direct benefits of disclosure, where a firm's disclosure affects its own liquidity and cost of capital, and (ii) the indirect benefit of disclosure, where a firm's disclosure affects the liquidity and cost of capital of peer firms in the industry. To the extent common owners incentivize their portfolio of firms to "internalize" the positive externalities of disclosure, these firms should increase disclosure.

As briefly noted earlier, improved liquidity is particularly useful for large institutional investors, which are the dominant common owners. Illiquidity significantly increases the trading

\footnotetext{
${ }^{9}$ Consistent with the idea that economic conditions are interrelated within an industry, Breuer et al. (2016), Baginski and Hinson (2016) and Arif and De George (2018) find that the disclosures of related firms can serve as substitutes for each other. Badertscher et al. (2013) find that disclosures of related firms can inform the investment decisions of peer firms and Shroff et al. (2014) find that disclosures of peer firms can reduce moral hazard cost for peer firms. Anilowski et al. (2007) and Bonsall et al. (2013) find that management earnings forecasts are informative about macroeconomic conditions. Further, several studies document intra-industry information transfers associated with disclosures (e.g., Foster, 1981; Baginski, 1987)
} 
costs for both active and passive investors. It is perhaps not surprising that active investors incur significant trading costs, but it might not be obvious why passive investors incur significant trading costs. Prior research (e.g., Boone and White, 2015; Bird and Karolyi, 2016; Schoenfeld, 2017) suggests that index-funds trade large volumes of stock on a daily basis to rebalance portfolios. Portfolio rebalancing needs arise because of capital inflows/outflows into such mutual funds as well as corporate actions such as dividend payments. Further, Schoenfeld (2017) reports that the overwhelming majority of index-fund trades occur in the open secondary market. Thus, to the extent, one firm's disclosure increases liquidity for several portfolio firms of a common owner, the reduction in transaction costs for common owners can be substantial, creating incentives for common owners to elicit more disclosure from their portfolio firms. ${ }^{10}$

Nevertheless, there are at least three reasons why we might not observe a positive association between common ownership and voluntary disclosure. First, co-owned firms continue to face competition from non-co-owned firms, which could impose significant proprietary costs of disclosure on co-owned firms. Second, prior research suggests that institutional investors have greater access to private information, and thus prefer less disclosure because it helps them maintain their information advantage (e.g., Bushee and Noe, 2000; Maffett, 2012). Thus, it is unclear whether the benefits of more disclosure from co-owned firms outweigh the cost of the reduction in common owners' information advantage. Finally, based on academic theory, it is unclear whether competition increases or decreases disclosure incentives.

\subsection{Can institutional investors influence firms' disclosure decisions?}

An important assumption in this paper is that common owners can influence firms' disclosure decisions. We base this assumption on prior research that finds that institutional

\footnotetext{
${ }^{10}$ It is also plausible that common owners use voluntary disclosure as a means to coordinate and implement collusive strategies. Pawliczek and Skinner (2018) provide evidence consistent with such a mechanism for why common ownership leads to increased disclosure. While we do not test the collusion hypothesis, our empirical tests attempt to isolate our proposed mechanisms, i.e., lower proprietary costs and greater externality benefits.
} 
investors have significant influence on corporate behavior, which includes not only firms' disclosure decisions but the entire spectrum of corporate decisions (e.g., payout policy, investment policy, governance provisions, etc.). For example, Appel et al. (2016) show that passive institutional investors influence governance choices, mainly through their large voting blocs, while Boone and White (2015), Bird and Karolyi (2016) Schoenfeld (2017) and Abramova et al. (2018) find that institutional investors influence disclosure decisions. Bushee $(1998,2001)$ and Aghion et al. (2013) find that institutional ownership affects both R\&D spending and innovation.

Prior research discusses two mechanisms through which blockholders can influence their portfolio firms' policies. First, they can actively influence firm policy. For example, they often have private communication with management. In a survey of institutional investors, McCahery et al. (2016) document that the most frequently used engagement channel is direct discussions with management. Blockholders can also actively influence firm policy through board member elections and shareholder proposals (Del Guercio and Hawkins, 1999). ${ }^{11}$ Institutional investors' voting can also credibly signal their informational preferences to the firm management (Boone and White, 2015). Documenting the impact of common ownership on institutional investors' voting decisions, He et al. (2018a) find that common owners are more likely to vote against management in shareholder-sponsored governance proposals, suggesting common owners take into account the negative externalities of poor governance on other portfolio firms.

Second, institutional investors that have flexibility in their choice of holdings could influence corporate policies indirectly through the threat of exit, i.e., selling their shares and driving down the share price (Edmans and Manso, 2011; Bharath et al., 2013; Gallagher et al., 2013). Managers who are sufficiently concerned about changes in stock price, ex ante, implement the desired policies of institutional investors to avoid ex post actual exit.

\footnotetext{
${ }^{11}$ Note that these actions are not limited to active investors. As noted above, Appel et al. (2016) find evidence that passive institutional investors influence firms' governance choices.
} 


\section{Research design, empirical proxies, and sample selection}

\subsection{Research design}

We estimate OLS regressions of the following form to test our prediction:

$$
\text { Disclosure }_{i, t}=\alpha_{i}+\alpha_{t} \times \alpha_{i n d}+\beta_{1} \text { Common } \text { Owner }_{i, t-1}+\gamma^{\prime} X+\epsilon_{i, t} .
$$

where $i$ and $t$ index firms and years, respectively; $\alpha_{i}$ and $\alpha_{t} \times \alpha_{\text {ind }}$ represent firm and year $\times$ industry fixed effects. We proxy for Disclosure using annual earnings and capex forecasts and CTO redactions. Common Owner is our proxy for common ownership at the firm-year level. $X$ is a vector of control variables based on prior research. All variables are described in the Appendix. Standard errors are clustered at the firm and year levels. Continuous variables are winsorized at the $1 \%$ and $99 \%$ levels. We use a linear probability model to estimate our regressions even when the dependent variable is an indicator because our regressions include several fixed effects. ${ }^{12}$

\subsection{Proxies for common ownership}

We extract institutional ownership data from Thomson Reuters's 13F database. ${ }^{13}$ We label institutional investors as blockholders if their ownership is at least five percent of a firm's outstanding shares. Common ownership arises when an institutional investor is simultaneously a blockholder in at least two firms operating in the same Hoberg and Phillips $(2010,2016) 300$ industry grouping (henceforth, HP300 industry) at a given point in time. We construct four proxies for common ownership at the firm-year level: Common Dummy, No. Common Firms, MV Common Firms, and No. Common Investors. Our first proxy, Common Dummy, is an indicator variable that equals one for firm-years in which at least one of the firm's institutional blockholders

\footnotetext{
${ }^{12}$ Using non-linear models, such as Logit or Probit, in the presence of fixed effects can result in inconsistent point estimates due to the incidental parameter problem (see Wooldridge, 2002; Angrist and Pischke, 2009).

${ }^{13}$ This dataset is known to be incomplete. To improve the accuracy of the data (as it relates to our research question), we search for missing institutional holding by plotting the total market value of each institutions holdings in each quarter. If an investor initially appears as a top-seven institution, then falls out of the list of top-ten institutions in the subsequent quarter and reappears in the top-seven list in the next quarter, we manually search Edgar for the investor's $13 \mathrm{~F}$ filing.
} 
simultaneously blockholds at least one other firm operating in the same industry. The second proxy, No. Common Firms, represents the number of same-industry firms that share at least one common owner with the focal firm (whose disclosure decisions we are studying). The third proxy, $M V$ Common Firms, is the sum of the market value of common owners' ownership in the sameindustry firms that share common ownership with the focal firm. Our final proxy, No. Common Investors, represents the number of unique institutional investors in a firm-year that simultaneously blockhold at least one other same-industry firm. We compute firm-year values for No. Common Firms, MV Common Firms and No. Common Investors using the average values of these proxies over the four quarters in each fiscal year. We $\log$ transform No. Common Firms, MV Common Firms and No. Common Investors to reduce skewness. ${ }^{14}$

Our common ownership proxies assume that firms operating in the same industry are economically related competitors. A similar assumption is (implicitly or explicitly) made in the majority of the studies examining the relation between product market characteristics and disclosure. We address concerns with this assumption by verifying the robustness of our inferences to alternative industry definitions, including the 4-digit NAICS and 4-digit SIC industry classification. For our main analyses, we follow Hoberg and Phillips (2010, 2016), who show that their industry classification approach (based on product description in $10-\mathrm{K}$ filings) better identifies product market competitors.

\subsection{Proxy for voluntary disclosure}

We focus on three forms of voluntary disclosure that prior research suggests are relevant to (i) firms' competitors, as these disclosures impose proprietary costs on the disclosing firm, and

\footnotetext{
${ }^{14}$ Another proxy for common ownership in an industry is the modified Herfindhal-Hirschman index delta, which captures the extent to which firms competing in a product market are connected through common owners (see e.g., Anton et al., 2018; Azar et al., 2018). Pawliczek and Skinner (2018) present evidence consistent with a positive association between common ownership and disclosure using the modified Herfindhal-Hirschman index delta to measure common ownership.
} 
(ii) investors in valuing the firm and mitigating adverse selection costs, and thus increasing liquidity. The first form of voluntary disclosure is management earnings forecasts. Prior studies find that earnings forecasts are one of the primary sources of forward-looking information concerning firm performance and expected demand (Beyer et al., 2010). Earnings forecasts not only convey information to the disclosing firms' investors but also to investors and managers of peer firms. For example, Baginski and Hinson (2016) find that the earnings forecasts of one firm affects the cost of capital of related firms in the industry, and Badertscher et al. (2013) find that such forecasts help inform the investment decisions of private firms operating in the same industry. In addition, several prior studies argue that management forecasts reveal proprietary information (see e.g., Bamber and Cheon, 1998; Li, 2010; Ali et al., 2014; Huang et al., 2017). However, these disclosures aggregate information rather than provide more granular information that might help competitors back out a firm's actions. Thus, earnings forecasts are less revealing of information that is directly exploitable by competitors. Further, earnings forecasts merely advance the disclosure of earnings news a few months. Thus, the extent to which earnings forecasts impose incremental proprietary costs on firms over those imposed by mandatory earnings disclosures is arguably limited (see Lang and Sul, 2014; Glaeser, 2018).

The second form of voluntary disclosure is management capital expenditure (capex) forecasts. We argue that capex forecasts provide more proprietary information, as these forecasts represent one of the largest expected future cash outlays by the firm. The importance and granularity of the information in a capex forecast can be quite valuable to investors. However, these forecasts can also be quite helpful to competitors, as this information reveals plans yet to be undertaken, thereby allowing time for competitors to take action in response to these plans. If firms are concerned of competitive harm, they are less likely to provide these forecasts.

We construct two disclosure proxies for each type of management forecast based on the probability and frequency of forecasting. Specifically, Earnings Guide (Capex Guide) is an 
indicator variable that equals one for firm-years with at least one annual earnings (capex) forecast. Earnings Forecast Freq (Capex Forecast Freq) is the number of annual earnings (capex) forecasts issued in a fiscal year. We log transform Earnings Forecast Freq and Capex Forecast Freq to reduce skewness. We focus on annual (rather than quarterly) forecasts because longer-horizon forecasts are more likely to reveal proprietary information.

The third form of voluntary disclosure is the degree to which firms redact information under an SEC confidential treatment order (Verrecchia and Weber, 2006). Regulation S-K requires firms to file their material contracts with their $8-\mathrm{K}, 10-\mathrm{K}, 10-\mathrm{Q}$, or registration statements. However, the SEC allows firms to request that proprietary information contained in the contract be withheld (subject to SEC approval). By definition, information redacted from a firm's contracts is proprietary. Examples of information that is typically redacted include cost and pricing data in supply contracts, and information in license agreements. We contend that this information is the most susceptible to proprietary costs of the three forms of disclosure, as this information is the most granular and factually based, as it relates to contractual details. However, contractual information could be idiosyncratic in nature and relevant only to the firm's immediate stakeholders and competitors, but relatively less helpful for peer firms in terms of liquidity spillover.

To identify redactions from firms' material contracts, we begin by identifying all 8-K, 10Q, and 10-K filings with at least one material contract (Exhibit 10) from the WRDS SEC Analytics Suite. We then search these filings for several keywords/phrases to identify the subset of contracts that contain redactions. ${ }^{15}$ We compute our proxy for (the inverse of) disclosure, \%Redaction, by

\footnotetext{
${ }^{15}$ Specifically, we use the following eight phrases to identify contracts containing redactions: "Rule 24b-2," "Rule 406," "FOIA," "CT Order," "confidential treatment ... (security and exchange commission or SEC)," "(security and exchange commission or SEC) ... confidential treatment," "application ... confidential treatment," "confidential (material or portion) ... (omit or redact)."
} 
taking the ratio of the number of material contracts with redactions to the total number of material contracts in firms' $8-\mathrm{K}, 10-\mathrm{Q}$ and $10-\mathrm{K}$ filings in a fiscal year. ${ }^{16}$

\subsection{Fixed effects and control variables}

We include several control variables to mitigate concerns that a correlated omitted variable affects our results. Importantly, all our regressions control for both firm- and year $\times$ industry-fixed effects. The inclusion of firm-fixed effects mitigates concerns that time-invariant firm characteristics affect the association between common ownership and disclosure. Further, by including firm-fixed effects, our regressions identify an association between common ownership and disclosure from within-firm changes in these variables. The inclusion of year $\times$ industry-fixed effects mitigate concerns that a time-trend, time-varying industry characteristic (e.g., degree of competition, industry concentration), or economy-wide shocks affect the relation between common ownership and disclosures. In addition to the fixed effects structure, our regressions control for several time-varying variables such as firm performance, changes in performance, growth opportunities, analyst coverage, firm size, leverage, forecasting difficulty, peer-firm forecasting activity, and auditor reputation. All variable definitions are provided in the Appendix. Importantly, we control for institutional ownership because prior research finds that institutional ownership is positively associated with disclosure (Ajinkya et al., 2005; Boone and White, 2015; Bird and Karolyi, 2016), and the percentage of the firm's shares owned by blockholders (Blockholder Ownership) because prior research finds that concentrated institutional

\footnotetext{
${ }^{16}$ We validate our approach to identify contracts with redacted information by cross-checking our approach to classify firm-years as having redactions with a classification created using the SEC's database on issuances of confidential treatment orders, which contains CTO issued from May 1, 2008 onwards (see https://www.sec.gov/edgar/searchedgar/ctorders.htm). Note that some degree of mismatch between redactions reported in the SEC database and that identified using our approach is to be expected because we classify firm-years as having a redaction based on the year in which the contract was filed with SEC while the SEC database reports the year in which the CTO was issued by the SEC. Despite this difference in approach, we find that there is over $75 \%$ overlap between our approach to identify firm-years as having at least one redacted contract and that report on the SEC website. Glaeser (2018) reports a similar degree of overlap.
} 
ownership is negatively associated with disclosure (Bamber and Cheon, 1998; Ajinkya et al., 2005). We also control for the extent to which a firm's blockholders also have blockholding in firms operating in a different industry, as Kang et al. (2018) find that institutional investors' monitoring effectiveness increases with the number of blockholdings. Given the similarity of this construct to our construct of interest, i.e., investors' blockholdings in same industry firms, we construct these proxies to mimic those we use for common ownership. We define these proxies (Common Ownership DiffInd) the same way we define our common ownership proxies except that we use different industry firms rather than same industry firms.

\subsection{Sample selection}

We create a sample of U.S.-listed firms with common stocks traded on the NASDAQ, NYSE, or AMEX between 1997 and 2015. Our sample begins in 1997 because the HP industry classification is unavailable prior 1996 and we require one year of lagged data to compute control variables. Further, when the disclosure proxy is earnings or capex forecasts, our sample begins in 1999 because the availability of management forecast data is sparse and often incomplete prior to 1998 (Anilowski et al., 2007; Chuk et al., 2013) and here again we require one year of lagged forecast data to compute control variables. Our sample period ends in 2015 because it is the last fiscal year for which the HP industry classification is available.

To be included in the sample, a firm requires to have positive total assets and to belong to an HP300 industry with at least two firms for each fiscal year. We obtain financial statement items from Compustat, stock return and data to calculate liquidity variables from CRSP and TAQ, analysts following and management earnings forecasts from IBES and quarterly institutional 13F holding data from Thomson Reuters. The final sample includes 54,541 and 66,455 firm-year observations for the management forecasts and redaction analysis, respectively (see Table 1). 


\section{Results}

\subsection{Descriptive statistics}

Table 2 provides summary statistics for the variables used in our analyses. We find that $27 \%$ (23\%) of our firm-years have issued at least one management earnings (capex) forecast. The average firm provides $1.18(0.74)$ earnings (capex) forecasts per year. Approximately $59 \%$ of firmyear observations in our sample are co-owned with at least one same-industry firm through at least one blockholder (Common Dummy). Figure 1 shows that common ownership (Common Dummy) has increased from below 5\% in 1980 to about $65 \%$ in $2016 .{ }^{17}$ The mean value of No. Common Firms is 9.39, indicating that the average commonly owned firm is connected to approximately 16 firms in the same-industry through a blockholder. ${ }^{18}$ The average firm has $46 \%$ institutional ownership, of which $15 \%$ is in the form of Blockholder Ownership.

To understand why common ownership has increased over the past two decades (per Figure 1), Table 3 presents the fraction of firms in Compustat that have a particular investor as one of its largest five shareholders from 1997 to 2015 . We focus on the ten largest institutional investors as of December, 311997 and 2015; we identify large institutional investors based on the number of firms in which they are one of the top-five owners. Table 3 reveals two important patterns: First, the fraction of firms in which institutional investors are a top-five shareholder has significantly increased from 1997 to 2015. For example, in 1999, besides Barclays, DFA and Fidelity, all other institutional investors were in the top-five shareholder list of fewer than $10 \%$ of the Compustat universe. Further, in 1997, Barclays, DFA and Fidelity were the top five owners in 27\%, 33\% and $17 \%$ of the Compustat universe, respectively. In contrast, in 2015, the fraction of firms in which Fidelity and DFA are the top-five owners has stayed roughly constant but BlackRock (Vanguard)

\footnotetext{
${ }^{17} \mathrm{We}$ create this figure using four-digit NAICS (rather than HP300) codes to provide a longer time trend. The trend is virtually the same when we use the HP300 industry classification for the restricted 1997 to 2015 period.

${ }^{18}$ We obtain a value of 16 firms connected via blockholders by dividing 9.39, the mean number of firms connected by common owners for the full sample of firm-years, by $59 \%$, the percent of firms co-owned in our sample.
} 
is one of the top-five owners in $61 \%(53 \%)$ of the Compustat universe. As such, institutional investors are now the largest owners in the majority of firms in the U.S. Second, the concentration of ownership by institutional investors has significantly increased over time, especially the ownership interest of BlackRock and Vanguard. As a result, a few large institutional investors now have common ownership in several public firms in the U.S.

\subsection{Relation between common ownership and voluntary disclosure}

Tables 4 and 5 report the results from estimating Equation 1 when the disclosure proxy is earnings and capex forecasts, respectively (where Guide is reported in Panel A and Forecast Freq is reported in Panel B). Across all specifications in both tables, the coefficient estimate for the common ownership proxy is positive and statistically significant at the $1 \%$ level. These coefficients indicate that common ownership is positively associated with (i) the likelihood of issuing both earnings and capex forecasts (Tables 4 and 5, Panel A), and (ii) the frequency of both earnings and capex forecasts (Tables 4 and 5, Panel B). In economic terms, column 1 in Table 4, Panel A shows that the coefficient for Common Dummy is 0.019 , indicating that commonly owned firms are approximately $9.5 \%(0.019 / 0.20)$ more likely to issue an earnings forecast than noncommonly owned firms. Similarly, column 1 in Table 4, Panel B shows that the coefficient for Common Dummy is 0.039 , which suggests that common ownership is associated with an $8.8 \%$ $\left(\left(\mathrm{e}^{0.039}-1\right) \times \frac{1+0.82}{0.82}\right)$ increase in the frequency of forecasting earnings. ${ }^{19}$ Table 5 provides similar inferences for capex forecasts. In particular, commonly owned firms are $22 \%$ more likely to issue a capex forecast, and provide $12.9 \%$ more capex forecasts than do non-commonly owned firms.

Tables 4 and 5 also show that the coefficient for Institutional Ownership is positive and significant in all regressions in panels A and B, while the coefficient for Blockholder Ownership

\footnotetext{
${ }^{19}$ The unconditional mean values of Earnings Guide and Earnings Forecast Freq (before taking the logarithm) for non-commonly owned firm-years are 0.20 and 0.82 , respectively (untabulated).
} 
is negative and significant across all specifications except one. These results are consistent with Ajinkya et al. (2005) who find that institutional ownership is positively associated with management forecasts but concentrated institutional ownership (i.e., blockholder ownership) is negatively associated with forecasts. The positive association between institutional ownership and disclosure is also consistent with recent evidence such as Boone and White (2015), Bird and Karolyi (2016) and Schoenfeld (2017). The coefficients for the other control variables are also largely consistent with that documented in prior research. Overall, the results in Tables 4 and 5 support our prediction that common ownership is associated with greater disclosure.

Table 6 reports the results from estimating Equation 1 when the voluntary disclosure proxy is \%Redaction. We find no evidence of a significant association between the common ownership proxies and \%Redaction. Since commonly owned firms face competition from non-commonly owned firms, it is perhaps not surprising to find that commonly owned firms, on average, do not reveal previously redacted information in their contracts. Disclosures that firms redact from contracts likely concern the most important proprietary information (otherwise firms would not redact this information), competition from non-commonly owned firms is likely a significant deterrent to disclosing previously redacted information in firms' contracts. However, we note that it is also plausible that common ownership is uncorrelated with firms' redaction decisions because the information in contracts do not generate as much spillover benefits to peers as management forecasts. Further, the decision to stop redacting information from a contract that was previously redacted perhaps requires consent from the counterparty to the contract. As such, it is unclear whether the absence of a relation between common ownership and redactions implies that common ownership does not significantly reduce proprietary costs.

\subsection{Does common ownership reduce proprietary cost concerns?}

We conduct two tests to identify the mechanism that gives rise to the positive relation between common ownership and disclosure. Our first test focuses on the proprietary cost 
mechanism-i.e., disclosure increases when proprietary costs decrease through common ownership. In particular, we examine whether the relation between common ownership and disclosure is stronger when a larger fraction of the industry is composed of commonly owned firms. Since not all industry competitors are commonly owned, common ownership reduces, but does not eliminate, proprietary costs of disclosure. As the portion of non-commonly owned firms in an industry decreases, proprietary costs for the disclosing commonly owned firms also decrease. Thus, we predict that the relation between common ownership and disclosure is stronger in industry-years where there is greater industry-wide common ownership.

To test this prediction, we construct an indicator variable, High Industry Common Own, that equals one for industry-years with high-levels of common ownership. Specifically, we compute the market share-weighted percentage of commonly owned firms for each industry-year (i.e., the market share-weighted percentage of firms with Common Dummy =1), where market shares are calculated based on firm sales. We then classify industry-years with above median values of market-share weighted common ownership as belonging to industries with high common ownership. We modify Equation 1 by including an interaction term between our common ownership proxies and High Industry Common Own to test our prediction. Note that the main effect of High Industry Common Own is subsumed by the Year $\times$ Industry fixed effects.

Table 7, Panel A (B, C) presents the results using earnings forecasts (capex forecasts; CTO redactions) as the disclosure proxy. Panel A (B) shows that in five (eight) out of the eight earnings (capex) forecast specifications, the coefficient for Common Ownership Proxy $\times$ High Industry Common Own is positive and significant. These coefficients suggest that the relation between common ownership and management forecasts is stronger when a larger fraction of the industry is owned by the same investors. Interestingly, Panel C shows that in three of the four regressions with \%Redaction as the dependent variable, the coefficient for Common Ownership Proxy $\times$ High Industry Common Own is negative and significant. The results in Panel $\mathrm{C}$ suggest that while 
managers are hesitant to reverse redaction decisions on average, they are more likely to do so when the fraction of firms in the industry that are connected through common owners increases. These results suggest that managers are less likely to redact information from material contracts only when they perceive the proprietary costs to be significantly lower (as reported in Table 6 and as observed from the insignificant main effect of common ownership in Table 7).

\subsection{Does common ownership lead firms to internalize disclosure externalities?}

Next, we examine whether co-owned firms increase disclosure to internalize the externalities of their disclosure. Specifically, we examine whether changes in information asymmetry for one firm, and thus the demand for public information by the investors of that firm, elicits a change in disclosure by co-owned peer firms. To test this prediction, we employ the setting originally used by Kelly and Ljungqvist (2012) and Derrien and Kecskes (2013) who show that when brokerage houses close or merge, some firms experience an exogenous loss of analyst coverage. Such losses in analyst coverage lead to an increase in information asymmetry and consequently a decrease in external financing and investment. Balakrishnan et al. (2014) argue that such exogenous losses in analyst coverage increase the marginal benefit of disclosure and go on to show that firms respond to losses in analyst coverage by increasing disclosure.

We hypothesize that when one firm experiences a loss in analyst coverage, the externality benefit of a peer-firm's disclosure increases. As a result, we predict that firms increase disclosure in response to a loss in analyst coverage for their co-owned peer firms. In other words, if firms do indeed consider the spillover effects of their disclosure on co-owned peer firms when making disclosure decisions, then firms should increase disclosure in response to a loss of public information for co-owned peer firms.

To test our prediction, we obtain a list of 43 brokerage house mergers or closures from Kelly and Ljungqvist (2012) and construct a sample of firms that lose analyst coverage as a result of these events. We refer to the firms experiencing such exogenous losses in analyst coverage as 
Affected Peers. We then construct a sample of firms that operate in the same industry as an Affected Peer but do not experience a loss of analyst coverage from the broker closures/mergers. From this sample of unaffected firms, we classify firm-years as treatment (control) firms if they share (do not share) at least one blockholder with an Affected Peer in the year. Importantly, we drop all Affected Peers from our analyses because prior research finds that these firms increase disclosure in response to the loss of analyst coverage (Balakrishnan et al., 2014). In other words, our analysis excludes firms that lose analyst coverage due to broker closures/mergers, and focuses on firms in the same industry that do not lose analyst coverage due to a broker closure/merger. We predict that treated firms increase voluntary disclosure (relative to control firms) to partially compensate for the exogenous increase in information asymmetry experienced by their co-owned peer firms (i.e., Affected Peers). We estimate the following difference-in-differences regression to test our prediction:

$$
\begin{aligned}
\text { Disclosure }_{c, i, j, t} & =\alpha_{c} \times \alpha_{i} \times \alpha_{j}+\alpha_{t}+\beta_{1} \text { Treatment Closure } \times \text { Post Closure } \\
& +\beta_{2} \text { Treatment Closure } \times \text { Pre [-1] Closure }+\beta_{3} \text { Post Closure } \\
& +\beta_{4} \text { Pre [-1] Closure }+\beta_{5} \text { Treatment Closure }+\gamma^{\prime} X+\epsilon_{c, i, j, t}
\end{aligned}
$$

where $c, i, j$, and $t$ index closure/merger events, Affected Peers, treated or control firms, and years respectively. It is worth noting that the unit of observation for this test is at the "Broker Closure""Affected Peer"-“Firm"-“Year" level. Each broker closure can affect analyst coverage for several firms (i.e., Affected Peers), and each Affected Peer shares industry membership with several firms that do not have a loss in analyst coverage - some of which are co-owned (i.e., treated firms) while others are not co-owned (i.e., control firms). However, the Affected Peers themselves, i.e., firms that lose analyst coverage due to a broker closure/merger, are excluded from our analysis. In the equation above, $\alpha_{c} \times \alpha_{i} \times \alpha_{j}$ represent closure/merger events $\times$ affected peers $\times$ firm fixed effects and $\alpha_{t}$ represent year fixed effects. Given the unit of analysis for this regression (described above), our regressions are identified in the presence of fixed effects for each broker closure, affected peer 
and firm combination. ${ }^{20}$ Disclosure is one of the five voluntary disclosure variables: (i) Earnings Guide, (ii) Earnings Forecasts Freq, (iii) Capex Guide, (iv) Capex Forecasts Freq or (v) $\%$ Redaction. Treatment Closure is an indicator variable that equals one for same-industry firms that share at least one blockholder with an Affected Peer and zero for same-industry firms that do not share any blockholder with any Affected Peer in a year. Post Closure is an indicator variable that equals one for the year after the broker closure/merger for both treatment and control firms. Pre [-1] Closure is an indicator variable that equals one for the year immediately before the broker closure/merger for both treatment and control firms. $X$ is a vector of control variables used in the baseline regression (Equation 1). Standard errors are clustered at the broker closure/merger level.

We highlight two features of our research design that help mitigate endogeneity concerns. First, we exploit the fact that broker closures/mergers are staggered over several years and thus affect different firms at different times during our sample period. The staggered design helps mitigate concerns that a confounding event around any one broker closure/merger explains our results. Second, we control for closure/merger events $\times$ affected peers $\times$ firms fixed effects; thus, the treatment effect is identified by comparing the change in disclosure of firms that share a common owner with an Affected Peer to the change in disclosure of same-industry firms that do not share a common owner with the same Affected Peer. As a result, our inferences are unlikely to be affected by alternative explanations related to industry or economy related shocks to disclosure incentives or concerns about reverse causality.

Table 8 presents the results from estimating Equation 2. Columns 1 and 3 present the results when Earnings Guide and Capex Guide are the dependent variables, respectively. The coefficient of Treatment Closure $\times$ Post Closure is positive in both regressions, but significant only for Capex Guide. The coefficient estimate in column 3 implies that treated firms are 2.7 percentage points

\footnotetext{
${ }^{20}$ A firm-year can be in our sample more than once if there are more than one Affected Peers in its industry in the year. Therefore, the number of observations in our sample of broker closure/merger test is greater than that of main tests.
} 
more likely to issue a capex forecast than control firms, on average. Columns 2 and 4 present the regression results when Earnings Forecasts Freq and Capex Forecasts Freq are the dependent variables, respectively. The coefficient estimate for Treatment Closure $\times$ Post Closure is positive and significant in both regressions. Column 5 shows that the coefficient for Treatment Closure $\times$ Post Closure is insignificant when the dependent variable is \%Redaction, which is consistent with our main results. Finally, Table 8 shows that the coefficient for Treatment Closure $\times$ Pre [-1] Closure is statistically insignificant for all five regressions, suggesting that there is no difference in pre-treatment disclosure between treated and control firms (consistent with the validity of the parallel trends assumption).

Overall, Table 8 shows that firms increase disclosure in response to losses in analyst coverage for their co-owned peer firms. Since the broker closures/mergers in our sample do not affect treated firms' information environment and only affect that of their co-owned peers, our results suggest that treated firms increase disclosure because they internalize the externalities of their disclosure for co-owned peers.

\section{Endogeneity: Analyses of financial institution mergers}

Institutional investors do not randomly invest, and it is plausible that common ownership endogenously arises as a result of the typical disclosure practices followed by firms in an industry. Specifically, it is plausible that institutional investors have a preference for firms that provide more voluntary disclosure; if the voluntary disclosure practices of firms in an industry are correlated then we might observe greater common ownership in that industry. Alternatively, institutional blockholders might be better at picking stocks with better future prospects, which also tend to provide more voluntary disclosures (e.g., Miller, 2002). To mitigate such endogeneity concerns, we follow He and Huang (2017) who use financial institution mergers to generate plausibly exogenous variation in common ownership. 
Financial institutions such as asset management companies, bank holding companies, security brokers, etc. often merge for reasons unrelated to the fundamentals of their portfolio holdings. When two financial institutions merge, the acquirer takes over the portfolios of the target, creating increases in common ownership for some portfolio firms while leaving the degree of common ownership in other portfolio firms unchanged. For example, when BlackRock acquired Barclays in 2009, BlackRock was a blockholder in Williams Clayton Energy Inc. in the Oil and Gas Extraction industry while Barclays was a blockholder in fifteen other firms in the same industry but not Williams Clayton Energy. Thus, the merger created additional common ownership links between Williams Clayton Energy and the fifteen firms Barclays owned. These newly formed common ownership links are plausibly exogenous to the disclosure incentives of these firms. Our identifying assumption is that institutions merge for reasons unrelated to their portfolio firms' disclosure decisions. ${ }^{21}$

We obtain a list of six financial institution mergers that occurred during our sample period from He and Huang (2017). ${ }^{22}$ We identify treated firms as those which experience an increase in common ownership due to the financial institution mergers. Specifically, to be included in the treatment group, a firm has to satisfy two conditions in the quarter before the merger announcement: (i) the firm is blockheld by one of the merging institutions, and (ii) the other merging institution does not blockhold the same firm, but blockholds at least one of its sameindustry peers. Importantly, the procedure to identify treated firms uses only ex ante information available at the time of the merger. This ex ante approach mitigates the concern that assignment

\footnotetext{
${ }^{21}$ Consistent with the validity of our identifying assumption, prior research suggests that financial institution mergers are typically a response to financial sector deregulations (see e.g., Houston et al., 2001). For instance, commercial banks were allowed to directly acquire existing investment banks as Section-20 subsidiaries in 1997. Further, following the Gramm-Leach-BlileyAct of 1999, commercial banks, investment banks, securities firms, and insurance companies were allowed to consolidate. He and Huang (2017) discuss that changes in regulations led to a wave of financial institution mergers in the 2000s, which covers our entire sample period for this test.

${ }^{22}$ The mergers included in our sample are: (i) Wells Fargo \& Benson Associates in 2003, (ii) Bank of America \& Fleet Boston in 2004, (iii) Wells Fargo \& Strong Financial in 2005, (iv) Barclays \& Lehman Brothers in 2008, (v) Bank of America \& Merrill Lynch in 2009, and (vi) BlackRock \& Barclays in 2009.
} 
of treatment firms is affected by subsequent trading decisions of the merged entity, which might contain information about the future prospects of portfolio firms or their disclosure policies.

To control for differences in the investment and stock picking styles of the merging institutions, we create a control sample of firms that are simultaneously owned by at least one of the merging institutions but do not witness a change in common ownership. Specifically, to be included in the control sample, a firm has to satisfy two conditions in the quarter before the merger announcement: (i) the firm has to be blockheld by the same institution that blockholds a treated firm, and (ii) the other merging institution does not blockhold any peer firms from the same industry. Thus, the merger does not affect the common ownership of control firms and yet these control firms are (partially) owned by the merged institution. An important advantage of our identification approach is that we have six financial institution mergers that occurred at different times during our sample period. The presence of multiple shocks mitigates the concern that confounding events around any one merger explains our results. ${ }^{23}$ We estimate the following difference-in-differences regression to compare the disclosure of treated and control firms:

$$
\begin{aligned}
\text { Disclosure }_{i, j, t}= & \alpha_{i} \times \alpha_{j}+\alpha_{t}+\beta_{1} \text { Treatment } \times \text { Post }+\beta_{2} \text { Treatment } \times \text { Pre }[-1]+ \\
& +\beta_{3} \text { Post }+\beta_{4} \text { Pre }[-1]+\gamma^{\prime} X+\epsilon_{i, t .}
\end{aligned}
$$

where $i, j$, and $t$ index firms, mergers, and years respectively; $\alpha_{i} \times \alpha_{j}$ and $\alpha_{t}$ represent firm $\times$ merger and year fixed effects, respectively. Disclosure is one of the five disclosure variables: (i) Earnings Guide, (ii) Earnings Forecasts Freq, (iii) Capex Guide, (iv) Capex Forecasts Freq or (v) \%Redaction. Treatment is an indicator variable that equals one for treated firms and zero for control firms. We include firm-year observations for one year after each merger and three years before each merger. We restrict the post-merger period to one year because we find that merger induced increases in common ownership declines after the year immediately following the merger (untabulated). Post is an indicator variable that equals one for the fiscal year following the financial

\footnotetext{
${ }^{23}$ Azar et al. (2018) use just the BlackRock-Barclays merger to generate exogenous variation in common ownerships at the industry level. In untabulated analyses, we follow their approach and find evidence consistent with our predictions. However, we use our multiple mergers setting to mitigate the effect of confounding event.
} 
institution mergers and zero for other years. Pre [-1] is an indicator variable that equals one for firm-year observations in the fiscal year immediately preceding the mergers.

$X$ is a vector of control variables used in the baseline regression (Equation 1). However, we change the fixed effects structure to include firm $\times$ merger indicators and year indicators, rather than firm and industry $\times$ year fixed effects. We make this research design choice because the treatment firms, by construction, operate in different industries than control firms. Thus, the inclusion of industry $\times$ year fixed effects subsumes part of the treatment effect. ${ }^{24}$ The treatment effect is identified from changes in disclosure for the same firm following a change in common ownership that results from a financial institution merger. Such changes in disclosure are benchmarked to changes in disclosure of other firms owned by the merging institution that do not experience a change in common ownership resulting from the merger. In this specification, Treatment is not identified because the regressions include firm $\times$ merger fixed effects. However, the coefficients for Post and Pre [-1] are identified despite the inclusion of year fixed effects because the post-period occurs in different fiscal years for firms treated by the different financial institution mergers in our sample. Standard errors are clustered at the firm and year level. ${ }^{25}$

Table 9 presents the results from estimating Equation 3. Columns 1 and 3 present the results when Earnings Guide and Capex Guide are the dependent variables, respectively. The coefficient of Treatment $\times$ Post is positive and significant in both regressions. The coefficient estimate implies that treated firms are, on average, 5.5 (6.9) percentage points more likely to issue an earnings (capex) forecast when common ownership increases as a result of a financial institution merger relative to the change in forecasting behavior of control firms (which are also blockheld by the same merging institution over the same period). Compared to the pre-merger average value of 0.48 (0.34) (untabulated) for Earnings Guide (Capex Guide), the coefficient estimates imply that

\footnotetext{
${ }^{24}$ Since we do not include industry $\times$ year fixed effects in this analysis, time-varying industry level variables, such as the Herfindhal index, are identified and thus included as a control variable in the regressions.

${ }^{25}$ Ideally, we would cluster standard errors based on the source of treatment - i.e., financial institution mergers. However, since we have only six mergers in our sample period, we have too few clusters at the merger-level to reliably estimate standard error clustered at the merger-level.
} 
forecasting probability increases by $11.5 \%(0.055 / 0.48)$ and $20.3 \%(0.069 / 0.34)$ due to changes in common ownership induced by financial institution mergers.

Column 2 and 4 present the regression results when Earnings Forecasts Freq and Capex Forecasts Freq are the dependent variables, respectively. The coefficient estimate for Treatment $\times$ Post is positive in both regressions, but significant only for Capex Forecasts Freq. Considering the pre-merger average value of Capex Forecasts Freq is 0.41 (untabulated), the coefficient estimates imply that frequency of providing capex forecasts increases by $28.3 \%(0.116 / 0.41)$ as a result of changes in common ownership induced by financial institution mergers. The coefficient of Treatment $\times$ Post is insignificant when the dependent variable is \%Redaction, which is consistence with our main results. Overall, Table 9 shows that the firms that experience an increase in their common ownership as a result of financial institution mergers provide more forecasts after the merger than those without changes in their common ownership.

To test for existence of pre-treatment trends, our regressions include an interaction term between an indicator variable for fiscal year preceding each financial institution merger (Pre [-1]) and the treatment indicator. Table 9 show that coefficient for Treatment $\times$ Pre [-1] is insignificant in all regressions, suggesting that the pre-treatment disclosure trends for treated and control firms are statistically indistinguishable.

Although the above test has several advantages, which help mitigate endogeneity concerns related to our main tests, we note that it has two limitations. Most importantly, there are relatively few firms receiving treatment as a result of the financial institution mergers, which limits the power of the test. In particular, the six mergers during our sample period affect the common ownership of just 111 firms, only ten of which had no common ownership before the merger. That is, the addition of a common owner for most of the sample (101 of the 111 firms receiving treatment) is an incremental effect. As a result, the test has limited generalizability and is of lower power, which likely (i) contributes to the muted significance of our results and (ii) limits the variation needed to 
conduct our cross-sectional tests (which is why we do not use the merger setting to conduct our main analyses). In addition, when exploring the data in more detail, we observed that the changes in common ownership due to mergers are often temporary. This is not surprising as the merged entity is likely to rebalance its portfolio following the merger. Accordingly, we expect that a firm's incentive to change disclosure in response to predictably transitory changes in common ownership is weaker than with more permanent common ownership. ${ }^{26}$

To address the limitations of the financial institution merger test, we conduct an additional test using a more stringent fixed effects structure than that employed in our main analyses. Specifically, in additional analyses, we re-run our main analyses controlling for blockholder fixed effects. The inclusion of blockholder fixed effects in our regressions holds the blockholderownership pattern of the disclosing firm constant and identifies the effect of common ownership on disclosure using changes in the other portfolio holdings of a firm's investor base. For example, let's say that Vanguard is a blockholder in company XYZ; by controlling for blockholder fixed effects (along with Firm and Year $\times$ Industry fixed effects), our regressions are testing whether company XYZ increases disclosure when Vanguard initiates a blockholding in another company in the same industry as company XYZ. ${ }^{27}$ The inclusion of blockholder fixed-effects not only mitigates concerns related to omitted variables and reverse causality but also addresses the concern that individual common owner's might have idiosyncratic preference for voluntary disclosure, which explains our results.

Table 10 Panel A (B, C, D, E) presents the results our main analyses after controlling for blockholder fixed effects when Earnings Guide (Earnings Forecast Freq; Capex Guide; Capex Forecast Freq; \%Redactions) is the dependent variable. The panels show that our inferences are

\footnotetext{
${ }^{26}$ Although there are some limitations with the financial institution merger test as an exogenous shock, we would like to highlight that the broker closure test serves as an additional test using an exogenous shock to provide more support for our inferences.

${ }^{27}$ Note that despite its identification benefits, we do not include blockholder fixed effects in our main tests tabulated in the paper because these fixed-effects partially control for treatment we are seeking to identify.
} 
unaffected by the inclusion of blockholder fixed effects, even though the statistical significance of the results is weaker. Specifically, we continue to find that common ownerships is positively associated with both proxies for earnings and capex guidance, but insignificantly associated with redactions. These results reinforce our main inference and further mitigate endogeneity concerns.

\section{Additional analyses and robustness tests}

\subsection{Market liquidity}

Common owners are mostly large investors who could meet with managers privately (e.g., Solomon and Soltes, 2015; Bushee et al., 2018). Thus, it is not obvious how common owners benefit from increased public disclosure. We argue that common owners have a preference for greater public disclosure because of its effect on liquidity. Common owners benefit from improved liquidity for two reasons. First, improved liquidity lowers cost of capital and hence increases the market value of their portfolio firm (Amihud, 2002). Second, improved liquidity lowers trading costs for investors. Large institutional investors (who account for much of the common ownership) trade fairly frequently to rebalance their portfolios (e.g., passive investors) and to profit from their private information (e.g., active investors). Such increases in liquidity are not an outcome that is possible via private discussions with firms, as the investing public needs to learn of the information to impact market liquidity. Thus, common owners benefit from increased public disclosure via its effect on liquidity (Diamond and Verrecchia, 1991; Shroff et al., 2013; Balakrishnan et al., 2014).

To examine the effects of common ownership on liquidity, we estimate Equation 1, but change the dependent variable from disclosure to liquidity proxies. We also change the set of control variables to match the dependent variable. We employ two proxies for liquidity: sizeweighted effective bid-ask spreads (BidAsk) and Amihud (2002)'s proxy for price impact of trades

(Amihud). The vector of control variables includes the natural logarithm of stock price to control for order processing costs, the natural logarithm of the standard deviation of daily returns and share 
turnover to control for holding costs. We include the natural logarithm of one plus the number of analysts following a firm and total assets to control for information environment. Finally, we control for the percentage of the firm's shares owned by blockholders, institutional ownership percentage, and different-industry common ownership proxies to explore the incremental effect of common ownership. Variable definitions are provided in the Appendix.

Table 11 reports the results for our regressions (where BidAsk is reported in Panel A and Amihud is reported in Panel B). Across all specifications (based on two proxies for liquidity and four proxies for common ownership), we find that the coefficient for the common ownership proxy is negative and statistically significant. These results suggest that common ownership is associated with increased liquidity. In terms of economic significance, firms with common ownership, on average, experience about a $2.5 \%(0.35 / 13.83)$ lower spread and a $2.4 \%\left(\mathrm{e}^{-0.024}-1\right)$ lower Amihud illiquidity measure. ${ }^{28}$ These effects are the incremental effects of common ownership after controlling for institutional ownership and blockholder ownership in the focal firm.

\subsection{Untabulated robustness tests}

We conduct a number untabulated robustness tests to further validate our inferences and mitigate endogeneity concerns. First, following Ajinkya et al. (2005), we conduct Granger causality tests to verify that common ownership leads to changes in firms' disclosure behavior. The Granger causality test isolates the incremental effect of lagged common ownership on disclosure (our effect of interest) after controlling for the potential effects of lagged disclosure on common ownership. Specifically, Granger (1969) proposes a test for causality that involves conducting F-tests to see whether lagged information of one variable, X, (i.e., common ownership) provides any statistically significant information about a second variable, Y, (i.e., disclosure) in the presence of lagged values of that second variable (i.e., disclosure). If yes, then X (i.e., common ownership) Granger causes Y (disclosure). We perform the Granger test by calculating F-statistics

\footnotetext{
${ }^{28}$ The unconditional average of values for BidAsk (Amihud) for non-commonly owned firms is 13.83 (3.21).
} 
that compares the explanatory power of an unrestricted model to that of a restricted model. We add Disclosure $t-1$, Disclosure t-2 $_{2}$, Disclosure $t-3$ to the Equation 1 to obtain the unrestricted model

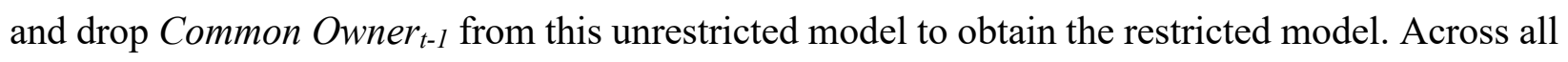
four proxies for common ownership and four proxies for management forecasts, the F-statistics rejects the null hypothesis of Common owner $_{t-1}=0$. In addition, consistent with our main results, we find that the F-statistics fails to reject the null hypothesis of Common Owner t- $_{1}=0$ when the dependent variable is $\%$ Redaction across all four proxies for common ownership. These results are consistent with common ownership Granger causing disclosure.

Second, in an effort to tease out the effect on common ownership on disclosure via the externality channel, we test whether our results are robust to controlling for firm aspects that would likely explain proprietary costs. We find that common ownership is associated with an increase in disclosure even after controlling for proprietary costs, as proxied by pair-wise product similarity (Hoberg and Phillips, 2010; 2016), R\&D intensity, and intangible intensity. Our results are robust to including these proprietary cost controls in our regressions.

Finally, we conduct several robustness tests related to (i) using two other industry classification schemes (NAICS 4-digit; the SIC 4-digit), (ii) estimating a base-line regression model without control variable, (iii) using different fixed effect structures (firm and year; industry and year), and (iv) clustering standard errors at different levels (just firm; just year). Our inferences are qualitatively similar.

\section{Conclusion}

This paper studies the effects of common ownership on the voluntary disclosure of coowned firms. Prior research indicates that competition decreases the aggregate profits of the competing firms and thus investors that own large stakes in several firms in the industry - i.e.,

common owners, have incentives to soften the intensity of competition to increase their aggregate portfolio value. To the extent these co-owned firms are less competitive with each other, we argue 
they are likely to be less concerned that proprietary information conveyed in their disclosures will be used by competitors at the expense of the disclosing firm. In addition, because disclosure by one firm has positive externalities for peer firms, firms and common owners also obtain indirect benefits from disclosure. Increased disclosure is beneficial to both firms and common owners, as it can reduce the cost of capital and increase liquidity, which is particularly important for large institutional investors, which need to frequently readjust their portfolio weightings.

We provide evidence that common ownership is associated with greater voluntary disclosure of management forecasts of earnings and capital expenditures. However, we do not find a relation between common ownership and the disclosure of more granular proprietary information contained in firms' material contracts. To support our inferences, we conduct two cross-sectional tests that show that common ownership affects disclosure through both the externality mechanism and through a reduction in proprietary costs. To address potential endogeneity concerns, we use financial institution mergers as plausibly exogenous sources of variation in common ownership, and our results are robust. Finally, our results show that common ownership increases market liquidity of co-owned firms, suggesting that increased disclosure benefits these firms and their common owners. 


\section{References}

Abramova, I., Core, J. E. and Sutherland, A. (2018). Institutional Investor Attention and Firm Disclosure. Working Paper.

Admati, A. R. and Pfleiderer, P. (2000). Forcing firms to talk: Financial disclosure regulation and externalities. The Review of Financial Studies, 13(3):479-519.

Aghion, P., Van Reenen, J. and Zingales, L. (2013). Innovation and Institutional Ownership. American Economic Review, 103(1): 277-304.

Ajinkya, B., Bhojraj, S., and Sengupta, P. (2005). The association between outside directors, institutional investors and the properties of management earnings forecasts. Journal of Accounting Research, 43(3):343-376.

Ali, A., Klasa, S., and Yeung, E. (2014). Industry concentration and corporate disclosure policy. Journal of Accounting and Economics, 58(2):240-264.

Amihud, Y. (2002). Illiquidity and stock returns: cross-section and time-series effects. Journal of Financial Markets, 5(1):31-56.

Angrist, J., Pischke, J.-S. (2009). Mostly Harmless Econometrics: An Empiricist's Companion. Princeton University Press, Princeton.

Anilowski, C., Feng, M. and D.J. Skinner (2007). Does earnings guidance affect market returns? The nature and information content of aggregate earnings guidance. Journal of Accounting and Economics, 44: 36-63

Anton, M., Ederer, F., Gin'e, M., and Schmalz, M. C. (2018). Common ownership, competition, and top management incentives. Working Paper.

Aobdia, D. (2018). Employee mobility, noncompete agreements, product-market competition, and company disclosure. Review of Accounting Studies, 23(1): 296-346.

Appel, I. R., Gormley, T. A., and Keim, D. B. (2016). Passive investors, not passive owners. Journal of Financial Economics, 121(1):111-141.

Arif, S. and De George, E. T. (2018). Does Financial Reporting Frequency Affect Investors' Reliance on Alternative Sources of Information? Evidence from Earnings Information Spillovers Around the World. Working Paper.

Azar, J. (2017). Portfolio diversification, market power, and the theory of the firm. Working Paper.

Azar, J., Raina, S., and Schmalz, M. C. (2016). Ultimate ownership and bank competition. Working Paper.

Azar, J., Schmalz, M. C., and Tecu, I. (2018). Anticompetitive effects of common ownership. The Journal of Finance, 74(4): 1513-1565.

Badertscher, B., Shroff, N., and White, H. D. (2013). Externalities of public firm presence: Evidence from private firms' investment decisions. Journal of Financial Economics, 109(3):682-706.

Baginski, S. P. (1987). Intraindustry information transfers associated with management forecasts of earnings. Journal of Accounting Research, 25(2):196-216.

Baginski, S. P. and Hinson, L. A. (2016). Cost of capital free-riders. The Accounting Review, 91(5):1291-1313. 
Balakrishnan, K., Billings, M. B., Kelly, B., and Ljungqvist, A. (2014). Shaping liquidity: On the causal effects of voluntary disclosure. The Journal of Finance, 69(5):2237-2278.

Bamber, L. S. and Cheon, Y. S. (1998). Discretionary management earnings forecast disclosures: Antecedents and outcomes associated with forecast venue and forecast specificity choices. Journal of Accounting Research, 36(2):167-190.

Bernard, D. (2016). Is the risk of product market predation a cost of disclosure?. Journal of Accounting and Economics, 62(2-3), 305-325.

Bernard, D., Burgstahler, D., Kaya, D. (2018). Size management by European private firms to minimize proprietary costs of disclosure. Journal of Accounting and Economics, 66(1), 94122.

Beyer, A., Cohen, D. A., Lys, T. Z., and Walther, B. R. (2010). The financial reporting environment: Review of the recent literature. Journal of Accounting and Economics, 50(2):296-343.

Bharath, S.T., Jayaraman, S. and Nagar, V. (2013). Exit as governance: an empirical analysis. Journal of Finance, 68: 2515-2547.

Bird, A. and Karolyi, S. A. (2016). Do institutional investors demand public disclosure? The Review of Financial Studies, 29(12):3245-3277.

Bonsall, S. B., Bozanic, Z. and Fischer, P. E. (2013). What Do Management Earnings Forecasts Convey About the Macroeconomy? Journal of Accounting Research, 51 (2): 225-266.

Boone, A. L., Floros, I. V., \& Johnson, S. A. (2016). Redacting proprietary information at the initial public offering. Journal of Financial Economics, 120(1), 102-123.

Boone, A. L. and White, J. T. (2015). The effect of institutional ownership on firm transparency and information production. Journal of Financial Economics, 117(3):508-533.

Bourveau, T. and Schoenfeld, J. (2017). Shareholder activism and voluntary disclosure. Review of Account Studies, 22(3): 1307-1339.

Breuer, M. Hombach, K. and Müller, M. A. (2016). When You Talk, I Remain Silent: Spillover Effects of Peers' Mandatory Disclosures on Firms' Voluntary Disclosures. Working Paper.

Bushee, B. J. (1998). The influence of institutional investors on myopic R\&D investment behavior. The Accounting Review 73(3): 305-333.

Bushee, B. J. (2001). Do institutional investors prefer near-term earnings over long-run value? Contemporary Accounting Research, 18 (2): 207-247.

Bushee, B. J., Gerakos, J., and Lee, L. F. (2018). Corporate jets and private meetings with investors. Journal of Accounting and Economics, 65(2-3), 358-379.

Bushee, B. J. and Goodman, T. H. (2007). Which institutional investors trade based on private information about earnings and returns? Journal of Accounting Research, 45(2):289-321.

Bushee, B. J. and Leuz, C. (2005). Economic consequences of SEC disclosure regulation: evidence from the OTC bulletin board. Journal of Accounting and Economics, 39(2):233-264.

Bushee, B. J. and Noe, C. F. (2000). Corporate disclosure practices, institutional investors, and stock return volatility. Journal of Accounting Research, 38:171-202. 
Chuk, E., Matsumoto, D., \& Miller, G. S. (2013). Assessing methods of identifying management forecasts: CIG vs. researcher collected. Journal of Accounting and Economics, 55(1): 23-42.

Coller, M. and Yohn, T. L. (1997). Management forecasts and information asymmetry: An examination of bid-ask spreads. Journal of Accounting Research, 35(2):181-191.

Darrough, M. N. (1993). Disclosure Policy and Competition: Cournot vs. Bertrand. The Accounting Review 68 (3): 534-61.

Darrough, M. N., and Stoughton, N. (1990). Financial disclosure policy in an entry game. Journal of Accounting and Economics 12, 219-243.

Dedman, E., \& Lennox, C. (2009). Perceived competition, profitability and the withholding of information about sales and the cost of sales. Journal of Accounting and Economics, 48(2-3), 210-230.

Del Guercio, D. and Hawkins, J. (1999). The motivation and impact of pension fund activism. Journal of Financial Economics, 52(3):293-340.

Derrien, F., and Kecskés, A. (2013). The real effects of financial shocks: Evidence from exogenous changes in analyst coverage. The Journal of Finance, 68(4): 1407-1440.

Diamond, D. W. (1985). Optimal release of information by firms. Journal of Finance 40: 1071-1094.

Diamond, D. W. and Verrecchia, R. E. (1991). Disclosure, liquidity, and the cost of capital. The Journal of Finance, 46(4):1325-1359.

Dye, R. A. (1990). Mandatory versus Voluntary Disclosures: The Cases of Financial and Real Externalities. The Accounting Review 65 (1): 1-24.

Edmans, A. and Manso, G. (2011). Governance through trading and intervention: a theory of multiple blockholders. Review of Financial Studies, 24 (7): 2395-2428.

Elhauge, E. (2017). The growing problem of horizontal shareholding. Competition Policy International, 3.

Foster, G. (1981). Intra-industry information transfers associated with earnings releases. Journal of Accounting and Economics, 3(3):201-232.

Gallagher, D. R., Gardner, P. A., and Swan, P. L. (2013). Governance through trading: Institutional swing trades and subsequent firm performance. Journal of Financial and Quantitative Analysis, 48(2):427-458.

Gilo, D., Moshe, Y., and Spiegel, Y. (2006). Partial cross ownership and tacit collusion. The RAND Journal of Economics, 37(1):81-99.

Glaeser, S. (2018). The Effects of Proprietary Information on Corporate Disclosure and Transparency: Evidence from Trade Secrets. Journal of Accounting and Economics, 66(1): 163-193.

Goodman, T. H., Neamtiu, M., Shroff, N., \& White, H. D. (2014). Management forecast quality and capital investment decisions. The Accounting Review, 89(1): 331-365.

Gordon, R. H. (1990). Do publicly traded corporations act in the public interest? Working Paper.

Graham, J. R., Harvey, C. R., and Rajgopal, S. (2005). The economic implications of corporate financial reporting. Journal of Accounting and Economics, 40(1):3-73. 
Granger, C. W. (1969). Investigating causal relations by econometric models and cross-spectral methods. Econometrica, 424-438.

Gutiérrez, G. and Philippon, T. (2017). Declining Competition and Investment in the U.S. NBER Working Paper.

Hansen, R. G. and Lott, J. R. (1996). Externalities and corporate objectives in a world with diversified shareholder/consumers. Journal of Financial and Quantitative Analysis, 31(1):43-68.

He, J. and Huang, J. (2017). Product market competition in a world of cross-ownership: Evidence from institutional blockholdings. The Review of Financial Studies, 30(8):2674-2718.

He, J., Huang, J., and Zhao, S. (2018a). Internalizing governance externalities: The role of institutional cross-ownership. Journal of Financial Economics, forthcoming.

He, J., Li, L., and Yeung, E. (2018b). Two tales of monitoring: Effects of institutional crossblockholding on accruals. Working paper.

Hoberg, G., \& Phillips, G. (2010). Product market synergies and competition in mergers and acquisitions: A text-based analysis. The Review of Financial Studies, 23(10): 3773-3811.

Hoberg, G. and Phillips, G. (2016). Text-based network industries and endogenous product differentiation. Journal of Political Economy, 124(5): 1423-1465.

Houston, J. F., James, C. M., and Ryngaert, M. D. (2001). Where do merger gains come from? Bank mergers from the perspective of insiders and outsiders. Journal of financial economics, 60(23): $285-331$.

Huang, Y., Jennings, R., and Yu, Y. (2017). Product market competition and managerial disclosure of earnings forecasts: Evidence from import tariff rate reductions. The Accounting Review, 92(3):185-207.

Jung, M. J. (2013). Investor overlap and diffusion of disclosure practices. Review of Accounting Studies, 18(1):167-206.

Kang, J.-K., Luo, J., and Na, H. S. (2018). Are institutional investors with multiple blockholdings effective monitors? Journal of Financial Economics, 128(3): 576-602.

Kelly, B., and Ljungqvist, A. (2012). Testing asymmetric-information asset pricing models. The Review of Financial Studies, 25(5): 1366-1413.

Lang, M. and Lundholm, R. (1996). Corporate disclosure policy and analyst behavior. The Accounting Review, 71: 467-492.

Lang, M. and Sul, E. (2014). Linking industry concentration to proprietary costs and disclosure: challenges and opportunities. Journal of Accounting and Economics, 58: 265-274.

Lee, C., \& Ready, M. J. (1991). Inferring trade direction from intraday data. The Journal of Finance, 46(2), 733-746.

Li, X. (2010). The impacts of product market competition on the quantity and quality of voluntary disclosures. Review of Accounting Studies, 15(3):663-711.

Li, Y., Lin, Y. and Zhang, L. (2017). Trade Secrets Law and Corporate Disclosure: Causal Evidence on the Proprietary Cost Hypothesis. Journal of Accounting Research, 56 (1): 265-308.

Liang, L. (2016). Common ownership and executive compensation. Working Paper. 
Lu, H., and Wu Tucker, J. (2012). Nonearnings corporate guidance. Financial Management, 41(4), 947-977.

Maffett, M. (2012). Financial reporting opacity and informed trading by international institutional investors. Journal of Accounting and Economics, 54(2):201-220.

McCahery, J. A., Sautner, Z., and Starks, L. T. (2016). Behind the scenes: The corporate governance preferences of institutional investors. The Journal of Finance, 71(6):2905-2932.

Miller, G. S. (2002). Earnings performance and discretionary disclosure. Journal of Accounting Research, 40(1):173-204.

Minnis, M., \& Shroff, N. (2017). Why regulate private firm disclosure and auditing?. Accounting and Business Research, 47(5), 473-502.

O’Brien, D. P. and Salop, S. C. (2000). Georgetown law. Antitrust Law Journal, 67(3):559-614.

Panayides, M.A. and Thomas, S. (2017). Commonality in Institutional Ownership and Competition in Product Markets. Working Paper.

Pawliczek, A. and Skinner, A. N. (2018). Common Ownership and Voluntary Disclosure. Working Paper,

Rotemberg, J. (1984). Financial transaction costs and industrial performance. Working Paper.

Rubin, A. (2006). Diversification and corporate decisions. Corporate Ownership and Control, 3(3):209-212.

Schmalz, M. (2015). How passive funds prevent competition. http://ericposner.com/martin-schmalzhow-passive-funds-prevent-competition/.

Schoenfeld, J. (2017). The effect of voluntary disclosure on stock liquidity: New evidence from index funds. Journal of Accounting and Economics 63: 51-74.

Shroff, N., Sun, A. X., White, H. D., and Zhang, W. (2013). Voluntary disclosure and information asymmetry: Evidence from the 2005 Securities Offering Reform. Journal of Accounting Research, 51(5):1299-1345.

Shroff, N., Verdi, R. and Yu, G. (2014). Information Environment and the Investment Decisions of Multinationals Corporations. The Accounting Review 89 (2): 759-790.

Shroff, N., Verdi, R. S., and Yost, B. P. (2017). When does the peer information environment matter? Journal of Accounting and Economics, 64 (2-3), 183-214.

Solomon, D., and Soltes, E. (2015). What are we meeting for? The consequences of private meetings with investors. The Journal of Law and Economics, 58(2): 325-355.

Verrecchia, R.E. (1982). Information Acquisition in a Noisy Rational Expectations Economy. Econometrica 50 (6): 1415-430.

Verrecchia, R. E. (1983). Discretionary disclosure. Journal of Accounting and Economics, 5:179-194.

Verrecchia, R.E. (1990). Information Quality and Discretionary Disclosure. Journal of Accounting and Economics 12: 365-380.

Verrecchia, R.E. (2001). Essays on disclosure. Journal of Accounting and Economics, 32(1): 97-180. 
Verrecchia, R. E. and Weber, J. (2006). Redacted disclosure. Journal of Accounting Research, 44(4):791-814.

Wooldridge, J. M. (2002). Econometric analysis of cross section and panel data. MIT Press, Cambridge, MA. 


\section{Variable Appendix}

Detailed definitions of all variables used in our empirical analyses

This table provides a detailed description of the procedures used to compute each variable used in our analyses. Our data are obtained either through Compustat, CRSP, I/B/E/S, TAQ, or the Thomson Reuters 13F database. All continuous variables are winsorized at $1 \%$ and $99 \%$ of the distribution. The variables are listed according to alphabetical order.

\begin{tabular}{|c|c|}
\hline Variable & Definition \\
\hline Amihud & $\begin{array}{l}\text { The natural logarithm of the annual average of the Amihud (2002) } \\
\text { illiquidity measure. The illiquidity measure is computed as the absolute } \\
\text { value of the daily stock returns divided by trading volume in dollar } \\
\text { amounts multiplied by } 1,000,000 \text {. Daily stock returns (RET), trading } \\
\text { volume (VOL*CFACSHR) and stock price (abs(PRC)/CFACPR) are } \\
\text { obtained from CRSP. }\end{array}$ \\
\hline Analysts & $\begin{array}{l}\text { The natural logarithm of one plus the number of analysts who make at } \\
\text { least one annual EPS forecast for the firm (NUMEST from IBES } \\
\text { STATSUM) }\end{array}$ \\
\hline Assets & The natural logarithm of total assets (AT from Compustat). \\
\hline BidAsk & 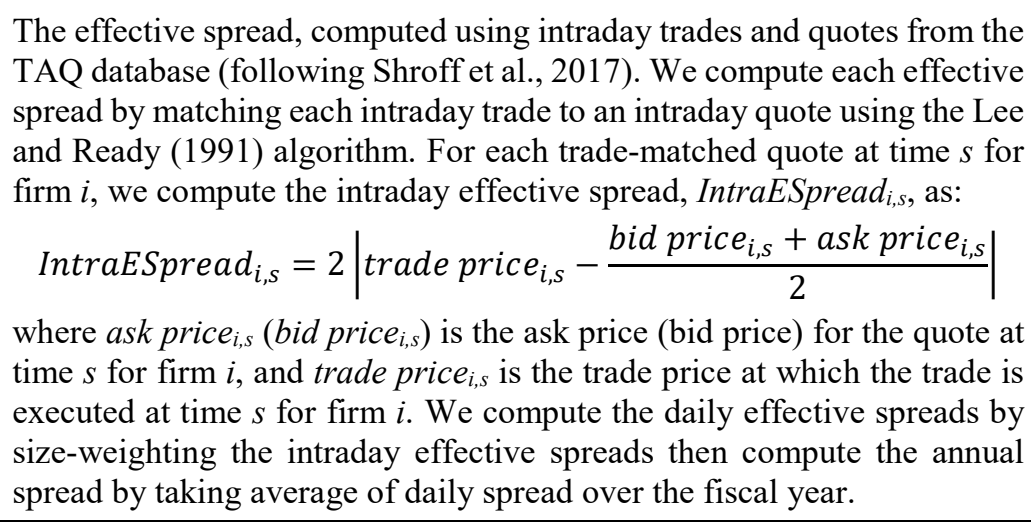 \\
\hline $\operatorname{BigN}$ & $\begin{array}{l}\text { Dummy variable which equals one if the firm's auditor is one of the big } \\
\mathrm{N} \text { auditors (AU from Compustat is smaller than 9), zero otherwise. }\end{array}$ \\
\hline Blockholder Ownership & $\begin{array}{l}\text { Blockholders' ownership percentage, measured as the sum of shares held } \\
\text { by blockholders (investors with at least } 5 \% \text { ownership), divided by total } \\
\text { number of shares outstanding (SHROUT*1,000,000 from Thomson } \\
\text { Reuters } 13 \mathrm{~F} \text { database). }\end{array}$ \\
\hline Capex Forecasts Freq & $\begin{array}{l}\text { The natural logarithm of one plus the number of management's capital } \\
\text { expenditure forecasts issued during the fiscal year. }\end{array}$ \\
\hline Capex Guide & $\begin{array}{l}\text { Dummy variable which equals one if the firm's management issues at } \\
\text { least one capital expenditure forecast during a fiscal year, zero otherwise. }\end{array}$ \\
\hline Common Dummy & $\begin{array}{l}\text { Dummy variable which equals one if the firm shares at least one } \\
\text { blockholder with at least one same-industry firm in at least one of the four } \\
\text { quarters of a fiscal year, zero otherwise. Industry is defined based on } \\
\text { Hoberg and Phillips }(2010,2016) 300 \text {-industry. }\end{array}$ \\
\hline Common Dummy DiffInd & $\begin{array}{l}\text { Dummy variable which equals one if the firm shares at least one } \\
\text { blockholder with at least one different-industry firm in at least one of the } \\
\text { four quarters of a fiscal year, zero otherwise. }\end{array}$ \\
\hline
\end{tabular}




\begin{tabular}{|c|c|}
\hline Common Ownership DiffInd & $\begin{array}{l}\text { This variable captures the extent to which a firm's investors have } \\
\text { blockholdings in different-industry firms. Given the similarity of this } \\
\text { variable to our variable of interest-i.e., investors' blockholdings in same } \\
\text { industry firms, we construct proxies for blockholding in different- } \\
\text { industry firms to mimic those we use for common ownership. } \\
\text { Specifically, when the common ownership proxy is Common Dummy, we } \\
\text { control for Common Dummy DiffInd, an indicator variable that equals one } \\
\text { for firm-years in which at least one of the firm's institutional blockholders } \\
\text { simultaneously blockholds at least one firm outside the focal firm's } \\
\text { industry. When the common ownership proxy is No. Common Firms, we } \\
\text { control for No. Common Firms DiffInd in our regressions. No. Common } \\
\text { Firms DiffInd is the number of unique firms that do not belong to the same } \\
\text { industry and share at least one institutional blockholder with the firm. } \\
\text { Similarly, we define No. Common Investors DiffInd and MV Common } \\
\text { Firms DiffInd using different-industry firms, and use them as control } \\
\text { variables in our regressions when the common ownership proxy is No. } \\
\text { Common Investors and MV Common Firms, respectively. }\end{array}$ \\
\hline Debt Issue & $\begin{array}{l}\text { Dummy variable which equals one if the firm issued debt (DLTIS from } \\
\text { Compustat) during the fiscal year. }\end{array}$ \\
\hline Earnings Forecasts Freq & $\begin{array}{l}\text { The natural logarithm of one plus the number of management's annual } \\
\text { EPS forecasts issued during the fiscal year. }\end{array}$ \\
\hline Earnings Guide & $\begin{array}{l}\text { Dummy variable which equals one if the firm's management issues at } \\
\text { least one annual EPS forecast during a fiscal year, zero otherwise. }\end{array}$ \\
\hline Earnings Increase & $\begin{array}{l}\text { Dummy variable which equals one if earnings before extraordinary (IB } \\
\text { from Compustat) is larger than that of the previous year's, zero otherwise. }\end{array}$ \\
\hline Equity Issue & $\begin{array}{l}\text { Dummy variable which equals one if the firm issued equity (from SDC } \\
\text { database) during the fiscal year. }\end{array}$ \\
\hline Herfindahl & Sum of squared of sales market shares for all firms in the firm's industry. \\
\hline High Industry Common Own & $\begin{array}{l}\text { Dummy variable that equals one if the firm belongs to an industry whose } \\
\text { Co-owned Percent is positive and above the median of industries with } \\
\text { positive Co-owned Percent, zero otherwise. Co-owned Percent is defined } \\
\text { as the market share-weighted average of Dummy Common in an industry. } \\
\text { Market share is computed based on sales (SALE from Compustat). }\end{array}$ \\
\hline Institutional Ownership & $\begin{array}{l}\text { Institutional ownership percentage, measured as the sum of shares held } \\
\text { by institutional investors, divided by total number of shares outstanding } \\
\text { (SHROUT } \times 1,000,000 \text { from Thomson Reuters } 13 \mathrm{~F} \text { database). }\end{array}$ \\
\hline Leverage & $\begin{array}{l}\text { The ratio of total debt to total assets measured at the beginning of the } \\
\text { fiscal year (LT/AT from Compustat). }\end{array}$ \\
\hline Loss & $\begin{array}{l}\text { Dummy variable which equals one if earnings before extraordinary items } \\
\text { (IB from Compustat) is negative, zero otherwise. }\end{array}$ \\
\hline$M T B$ & $\begin{array}{l}\text { The ratio of market value to book value of total assets measured at the } \\
\text { beginning of the fiscal year }((\mathrm{AT}+(\text { abs }(\mathrm{PRCC} \text { F }) \times \mathrm{CSHO}-\mathrm{CEQ})) / \mathrm{AT} \\
\text { from Compustat). }\end{array}$ \\
\hline MV Common Firms & $\begin{array}{l}\text { The natural logarithm of one plus the average market value of common } \\
\text { owners' ownership in the same-industry firms that are co-owned with the } \\
\text { focal firm over the four quarters of a fiscal year. }\end{array}$ \\
\hline
\end{tabular}




\begin{tabular}{|c|c|}
\hline MV Common Firms DiffInd & $\begin{array}{l}\text { The natural logarithm of one plus the average market value of common } \\
\text { owners' ownership in the different-industry firms that are co-owned with } \\
\text { the focal firm over the four quarters of a fiscal year. }\end{array}$ \\
\hline No. Common Firms & $\begin{array}{l}\text { The natural logarithm of one plus the average number of same-industry } \\
\text { firms that are co-owned with the focal firm over the four quarters of a } \\
\text { fiscal year. }\end{array}$ \\
\hline No. Common Firms DiffInd & $\begin{array}{l}\text { The natural logarithm of one plus the average number of different- } \\
\text { industry firms that are co-owned with the focal firm over the four quarters } \\
\text { of a fiscal year. }\end{array}$ \\
\hline No. Common Investors & $\begin{array}{l}\text { The natural logarithm of one plus the average number of the firm's } \\
\text { blockholders that are a blockholder of at least one same-industry firm } \\
\text { over the four quarters of a fiscal year. }\end{array}$ \\
\hline No. Common Investors DiffInd & $\begin{array}{l}\text { The natural logarithm of one plus the average number of the firm's } \\
\text { blockholders that are a blockholder of at least one different-industry firm } \\
\text { over the four quarters of a fiscal year. }\end{array}$ \\
\hline No. Stoppers & $\begin{array}{l}\text { The number of same-industry Stoppers. Stopper is defined as a firm that } \\
\text { issues at least one annual EPS forecast in each of years } \mathrm{t}-3 \text { and } \mathrm{t}-2 \text { but } \\
\text { does not issue any annual EPS forecast in year } \mathrm{t}-1 \text {. Management earnings } \\
\text { forecasts are obtained from IBES. }\end{array}$ \\
\hline Post & $\begin{array}{l}\text { Dummy variable which equals one for the fiscal year that starts } \\
\text { immediately after the effective date of the financial institutions mergers, } \\
\text { zero otherwise. }\end{array}$ \\
\hline Post Closure & $\begin{array}{l}\text { Dummy variable which equals one for the year that starts one month after } \\
\text { broker closures, zero otherwise. }\end{array}$ \\
\hline $\operatorname{Pre}[-1]$ & $\begin{array}{l}\text { Dummy variable which equals one for the fiscal year that ends } \\
\text { immediately before the announcement date of the financial institutions } \\
\text { mergers, zero otherwise. }\end{array}$ \\
\hline Pre [-1] Closure & $\begin{array}{l}\text { Dummy variable which equals one for the year that ends one month } \\
\text { before broker closures, zero otherwise. }\end{array}$ \\
\hline Price & $\begin{array}{l}\text { The natural logarithm of the average of the daily closing price } \\
\text { (abs(PRC)/CFACPR, from CRSP) over the year. }\end{array}$ \\
\hline \%Redaction & $\begin{array}{l}\text { Ratio of the number of }(10-\mathrm{K}, 10-\mathrm{Q} \text { or } 8-\mathrm{K}) \text { filling with at least one of the } \\
\text { redaction phrases to the total number of (10-K, 10-Q or } 8-\mathrm{K}) \text { fillings with } \\
\text { at least one material contract in a fiscal year. Redactions phrases are: } \\
\text { "Rule } 24 \mathrm{~b}-2, \text {,"Rule } 406 \text {," "FOIA," "CT Order," "confidential treatment } \\
\ldots \text { (security and exchange commission or SEC)," "(security and exchange } \\
\text { commission or SEC) ... confidential treatment," "application ... } \\
\text { confidential treatment," "confidential (material or portion) ... (omit or } \\
\text { redact)." }\end{array}$ \\
\hline$R O A$ & $\begin{array}{l}\text { Earnings before extraordinary items (IB from Compustat) over total } \\
\text { assets (AT from Compustat) at the beginning of the fiscal year. }\end{array}$ \\
\hline Sales growth & $\begin{array}{l}\text { Percentage change in sales, computed as (Sales - prior year's Sales)/Sales. } \\
\text { Sales is obtained from Compustat (SALE). }\end{array}$ \\
\hline Stdev. Earn & $\begin{array}{l}\text { The standard deviation of annual earnings before extraordinary items over } \\
\text { total assets (IB/AT from Compustat) over the past five years (with a } \\
\text { minimum of three years). }\end{array}$ \\
\hline
\end{tabular}




\begin{tabular}{|l|l|}
\hline Stdev. Return & $\begin{array}{l}\text { The natural logarithm of the standard deviation of daily returns (RET } \\
\text { from CRSP) over the year. }\end{array}$ \\
\hline Treatment & $\begin{array}{l}\text { Dummy variable which equals one if (i) the firm is blockheld by one of } \\
\text { merging institution in the quarter immediately before the announcement } \\
\text { of the merger and (ii) the other merging institution does not blockhold the } \\
\text { firm but blockholds at least one of its same-industry firms in the quarter } \\
\text { immediately before the announcement of the merger. }\end{array}$ \\
\hline Treatment Closure & $\begin{array}{l}\text { Dummy variable which equals one if the firm shares at least one } \\
\text { blockholder with at least one same-industry firm that experiences analyst } \\
\text { coverage termination due to a broker closure/merger. }\end{array}$ \\
\hline Turnover & $\begin{array}{l}\text { The natural logarithm of the average of daily trading volume divided by } \\
\text { shares outstanding (VOL/SHROUT from CRSP) over the year. }\end{array}$ \\
\hline
\end{tabular}




\section{Figure 1}

Common ownership over time

This figure plots the percentage of common ownership from 1980 to 2016 . The y-axis is the percentage of firms in our sample that are owned by at least one institutional blockholder that simultaneously blockholders at least one other same-industry firm. We define blockholders as investors with at least $5 \%$ ownership in a firm and classify industry by four-digit NAICS codes.

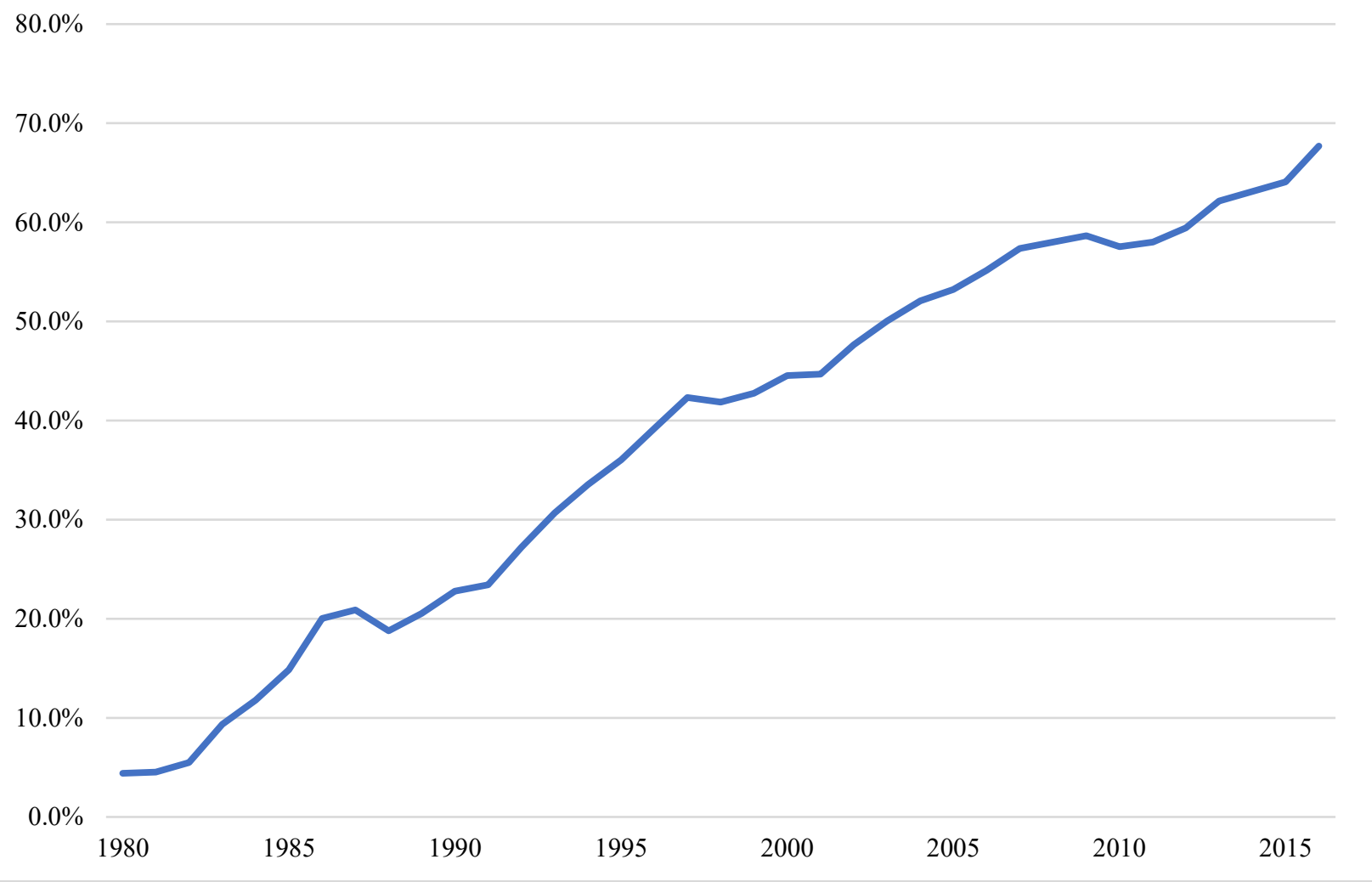


Table 1

Sample selection

\section{Description}

Table

No. of Firm-years

(i) Compustat firms on NYSE, NASDAQ, or AMEX with

(i) positive total asset for fiscal years from 1997 to 2015

91,681

Eliminate firm-years that:

do not have HP industry definition

are the only firm in the industry

(ii) Sample firm-year available for disclosure tests:

78,765

(a) missing control variables used for regressions with

(a) disclosure measured using forecasts

(b) missing control variables used for regressions with disclosure measured using redaction

(c) fiscal years ending before December 31, 1999

Table 4, Table 5,

(iii) Final sample for tests when disclosure proxy is earnings or capital expenditure forecasts (ii) - (a) - (c)

Table 7 (panels A \& B), Table 9 (panels A \& B),

Table 11 (panels A - D)

Table 6

(iv) Final sample for tests when dis

Table 7 (panel C),

Table 9 (panel C),

66,455

Table 11 (panel E)

Eliminate firm-years that:

(d) for the period 2013 to 2015

(e) are missing liquidity proxies

(f) are missing control variables for liquidity tests

(v) Final sample for liquidity tests (iii) - (d) - (e) - (f)

Table 12

36,905 
Table 2

Descriptive statistics

This table reports summary statistics for the variables used in our main analyses. Our sample is comprised of firms listed on the NASDAQ, NYSE, and AMEX between 1997 (1999) and 2015 when the disclosure proxy is CTO redactions (management forecasts). Definitions for all variables are provided in Variable Appendix.

\begin{tabular}{|c|c|c|c|c|c|c|}
\hline Variables & $\mathbf{N}$ & Mean & SD & $\mathbf{P 2 5}$ & P50 & P75 \\
\hline Earnings Guide & 54,541 & 0.27 & 0.45 & 0.00 & 0.00 & 1.00 \\
\hline Earnings Forecast Freq & 54,541 & 1.18 & 2.42 & 0.00 & 0.00 & 1.00 \\
\hline Capex Guide & 54,541 & 0.23 & 0.42 & 0.00 & 0.00 & 0.00 \\
\hline Capex Forecast Freq & 54,541 & 0.74 & 1.74 & 0.00 & 0.00 & 0.00 \\
\hline$\%$ Redaction & 66,455 & 0.04 & 0.16 & 0.00 & 0.00 & 0.00 \\
\hline BidAsk & 36,905 & 11.96 & 11.92 & 4.63 & 8.49 & 14.77 \\
\hline Amihud & 36,905 & 1.66 & 6.48 & 0.00 & 0.01 & 0.15 \\
\hline Common Dummy & 54,541 & 0.59 & 0.49 & 0.00 & 1.00 & 1.00 \\
\hline No. Common Firms & 54,541 & 9.39 & 20.06 & 0.00 & 1.25 & 8.75 \\
\hline MV Common Firms (in \$Bil) & 54,541 & 2.51 & 6.81 & 0.00 & 0.05 & 1.48 \\
\hline No. Common Investors & 54,541 & 1.04 & 1.20 & 0.00 & 1.00 & 1.75 \\
\hline Institutional Ownership & 54,541 & 0.46 & 0.34 & 0.10 & 0.49 & 0.76 \\
\hline Blockholder Ownership & 54,541 & 0.15 & 0.14 & 0.00 & 0.12 & 0.24 \\
\hline Common Ownership DiffInd & & & & & & \\
\hline Common Dummy DiffInd & 54,541 & 0.69 & 0.46 & 0.00 & 1.00 & 1.00 \\
\hline No. Common Firms DiffInd & 54,541 & 402.98 & 491.24 & 0.00 & 174.25 & 673.00 \\
\hline $\begin{array}{l}\text { MV Common Firms DiffInd (in } \\
\text { \$Bil) }\end{array}$ & 54,541 & 123.99 & 245.78 & 0.00 & 12.89 & 140.71 \\
\hline No. Common Investors DiffInd & 54,541 & 1.69 & 1.58 & 0.00 & 1.50 & 2.75 \\
\hline High Industry Common Own & 54,541 & 0.40 & 0.49 & 0.00 & 0.00 & 1.00 \\
\hline Loss & 54,541 & 0.26 & 0.44 & 0.00 & 0.00 & 1.00 \\
\hline$R O A$ & 54,541 & 0.01 & 0.17 & 0.00 & 0.03 & 0.08 \\
\hline $\operatorname{BigN}$ & 54,541 & 0.79 & 0.41 & 1.00 & 1.00 & 1.00 \\
\hline Analysts & 54,541 & 5.30 & 6.84 & 0.00 & 3.00 & 8.00 \\
\hline Earnings Increase & 54,541 & 0.59 & 0.49 & 0.00 & 1.00 & 1.00 \\
\hline Assets (in \$ Bil) & 54,541 & 8.04 & 63.50 & 0.16 & 0.71 & 2.82 \\
\hline$M T B$ & 54,541 & 1.91 & 1.57 & 1.06 & 1.37 & 2.07 \\
\hline Leverage & 54,541 & 0.54 & 0.26 & 0.33 & 0.53 & 0.72 \\
\hline No. Stoppers & 54,541 & 1.05 & 1.98 & 0.00 & 0.00 & 1.00 \\
\hline Herfindahl & 54,541 & 0.22 & 0.19 & 0.09 & 0.15 & 0.30 \\
\hline Stdev. Earn & 54,541 & 0.08 & 0.13 & 0.01 & 0.03 & 0.08 \\
\hline Sales growth & 54,541 & 0.04 & 0.29 & -0.03 & 0.06 & 0.16 \\
\hline Debt Issue & 66,455 & 0.54 & 0.50 & 0.00 & 1.00 & 1.00 \\
\hline Equity Issue & 66,455 & 0.09 & 0.29 & 0.00 & 0.00 & 0.00 \\
\hline Stdev. Return & 36,905 & 0.03 & 0.02 & 0.02 & 0.03 & 0.04 \\
\hline Turnover & 36,905 & 0.01 & 0.01 & 0.00 & 0.01 & 0.01 \\
\hline Price & 36,905 & 20.31 & 19.18 & 7.23 & 14.87 & 26.98 \\
\hline
\end{tabular}


Table 3

Fraction of firms in Compustat universe in which a given institutional investor is among the largest five owners

In the table below, we identify all institutional investors that are one of top-ten institutions in terms of the number of firms in which they are a top-five owner as of December 31, 1997 or December 31, 2015. This table presents the percentage of firms in the Compustat universe of public firms in which each unique institutional investor is one of the largest five shareholders.

\begin{tabular}{|c|c|c|c|c|c|c|c|c|c|c|c|c|c|c|c|c|c|c|c|}
\hline Institutional Investor & 1997 & 1998 & 1999 & 2000 & 2001 & 2002 & 2003 & 2004 & 2005 & 2006 & 2007 & 2008 & 2009 & 2010 & 2011 & 2012 & 2013 & 2014 & 2015 \\
\hline BlackRock Inc. & $3 \%$ & $3 \%$ & $2 \%$ & $2 \%$ & $1 \%$ & $0 \%$ & $1 \%$ & $1 \%$ & $1 \%$ & $2 \%$ & $3 \%$ & $2 \%$ & $54 \%$ & $47 \%$ & $50 \%$ & $50 \%$ & $50 \%$ & $52 \%$ & $61 \%$ \\
\hline Vanguard Group & $4 \%$ & $6 \%$ & $9 \%$ & $12 \%$ & $14 \%$ & $15 \%$ & $12 \%$ & $13 \%$ & $12 \%$ & $12 \%$ & $15 \%$ & $21 \%$ & $29 \%$ & $32 \%$ & $38 \%$ & $46 \%$ & $41 \%$ & $48 \%$ & $53 \%$ \\
\hline DFA & $33 \%$ & $29 \%$ & $30 \%$ & $28 \%$ & $31 \%$ & $29 \%$ & $23 \%$ & $20 \%$ & $20 \%$ & $19 \%$ & $20 \%$ & $23 \%$ & $22 \%$ & $20 \%$ & $20 \%$ & $20 \%$ & $18 \%$ & $19 \%$ & $20 \%$ \\
\hline Fidelity & $17 \%$ & $16 \%$ & $16 \%$ & $16 \%$ & $17 \%$ & $19 \%$ & $21 \%$ & $19 \%$ & $20 \%$ & $18 \%$ & $18 \%$ & $16 \%$ & $18 \%$ & $17 \%$ & $19 \%$ & $18 \%$ & $17 \%$ & $19 \%$ & $19 \%$ \\
\hline State Street Corp. & $1 \%$ & $2 \%$ & $3 \%$ & $4 \%$ & $6 \%$ & $8 \%$ & $10 \%$ & $7 \%$ & $7 \%$ & $6 \%$ & $6 \%$ & $9 \%$ & $10 \%$ & $9 \%$ & $10 \%$ & $12 \%$ & $9 \%$ & $13 \%$ & $12 \%$ \\
\hline Renaissance Tech. & $0 \%$ & $0 \%$ & $0 \%$ & $0 \%$ & $0 \%$ & $0 \%$ & $0 \%$ & $0 \%$ & $1 \%$ & $5 \%$ & $10 \%$ & $12 \%$ & $9 \%$ & $6 \%$ & $6 \%$ & $8 \%$ & $7 \%$ & $8 \%$ & $10 \%$ \\
\hline T. Rowe Price & $5 \%$ & $5 \%$ & $5 \%$ & $6 \%$ & $6 \%$ & $7 \%$ & $7 \%$ & $8 \%$ & $8 \%$ & $8 \%$ & $8 \%$ & $8 \%$ & $8 \%$ & $9 \%$ & $10 \%$ & $10 \%$ & $9 \%$ & $10 \%$ & $9 \%$ \\
\hline Wellington & $9 \%$ & $9 \%$ & $8 \%$ & $9 \%$ & $10 \%$ & $11 \%$ & $11 \%$ & $11 \%$ & $12 \%$ & $11 \%$ & $11 \%$ & $10 \%$ & $9 \%$ & $10 \%$ & $11 \%$ & $11 \%$ & $10 \%$ & $11 \%$ & $10 \%$ \\
\hline Capital Research \& Mgmt & $5 \%$ & $6 \%$ & $6 \%$ & $6 \%$ & $6 \%$ & $5 \%$ & $6 \%$ & $6 \%$ & $6 \%$ & $6 \%$ & $6 \%$ & $6 \%$ & $6 \%$ & $6 \%$ & $6 \%$ & $6 \%$ & $5 \%$ & $6 \%$ & $6 \%$ \\
\hline JP Morgan Chase & $4 \%$ & $3 \%$ & $3 \%$ & $6 \%$ & $5 \%$ & $3 \%$ & $3 \%$ & $3 \%$ & $4 \%$ & $3 \%$ & $3 \%$ & $3 \%$ & $3 \%$ & $3 \%$ & $4 \%$ & $5 \%$ & $0 \%$ & $0 \%$ & $12 \%$ \\
\hline CALPERS & $1 \%$ & $0 \%$ & $1 \%$ & $1 \%$ & $1 \%$ & $1 \%$ & $5 \%$ & $6 \%$ & $5 \%$ & $3 \%$ & $3 \%$ & $3 \%$ & $4 \%$ & $4 \%$ & $4 \%$ & $5 \%$ & $3 \%$ & $2 \%$ & $3 \%$ \\
\hline Mellon Bank Corp. & $8 \%$ & $8 \%$ & $9 \%$ & $9 \%$ & $8 \%$ & $7 \%$ & $5 \%$ & $4 \%$ & $5 \%$ & $12 \%$ & $3 \%$ & $0 \%$ & $3 \%$ & $3 \%$ & $3 \%$ & $3 \%$ & $26 \%$ & $0 \%$ & $1 \%$ \\
\hline Barclays Bank & $27 \%$ & $32 \%$ & $30 \%$ & $23 \%$ & $26 \%$ & $26 \%$ & $32 \%$ & $36 \%$ & $35 \%$ & $34 \%$ & $30 \%$ & $43 \%$ & $0 \%$ & $0 \%$ & $0 \%$ & $0 \%$ & $0 \%$ & $0 \%$ & $0 \%$ \\
\hline Putnam Investment Mgmt & $6 \%$ & $6 \%$ & $6 \%$ & $5 \%$ & $5 \%$ & $5 \%$ & $3 \%$ & $2 \%$ & $2 \%$ & $2 \%$ & $1 \%$ & $1 \%$ & $0 \%$ & $0 \%$ & $1 \%$ & $1 \%$ & $0 \%$ & $1 \%$ & $1 \%$ \\
\hline Traverlers Inc. & $7 \%$ & $10 \%$ & $7 \%$ & $7 \%$ & $7 \%$ & $7 \%$ & $7 \%$ & $5 \%$ & $5 \%$ & $9 \%$ & $9 \%$ & $9 \%$ & $1 \%$ & $1 \%$ & $1 \%$ & $3 \%$ & $1 \%$ & $2 \%$ & $1 \%$ \\
\hline ANB Investment Mgmt & $19 \%$ & $0 \%$ & $0 \%$ & $0 \%$ & $0 \%$ & $0 \%$ & $0 \%$ & $0 \%$ & $0 \%$ & $0 \%$ & $0 \%$ & $0 \%$ & $0 \%$ & $0 \%$ & $0 \%$ & $0 \%$ & $0 \%$ & $0 \%$ & $0 \%$ \\
\hline Bankers Trust & $3 \%$ & $4 \%$ & $6 \%$ & $8 \%$ & $0 \%$ & $8 \%$ & $7 \%$ & $3 \%$ & $4 \%$ & $5 \%$ & $5 \%$ & $3 \%$ & $3 \%$ & $2 \%$ & $2 \%$ & $2 \%$ & $8 \%$ & $0 \%$ & $0 \%$ \\
\hline
\end{tabular}


Table 4

Effect of common ownership on management earnings forecasts

This table presents the results from regressing voluntary disclosure on lagged common ownership and other determinants of disclosure. In Panel A, the proxy for voluntary disclosure is Earnings Guide, which is a dummy variable equal to one if the firm issues at least one annual earnings forecast during a fiscal year, and in Panel B, the proxy for voluntary disclosure is Earnings Forecast Freq, which is the natural log of one plus the number of annual EPS forecasts issued during the fiscal year. Continuous variables are winsorized at the $1 \%$ and $99 \%$ levels and are defined in the Variable Appendix. ${ }^{* * *, * * *}$ indicate statistical significance at the $10 \%, 5 \%$, and $1 \%$ levels, respectively, using a two-tailed $t$-test.

Panel A: Using Earnings Guide as the proxy for voluntary disclosure

(1) (2) (3)

(4)

\begin{tabular}{|c|c|c|c|c|c|}
\hline Dependent Variable: & Pr. Sign & \multicolumn{4}{|c|}{ Earnings Guide } \\
\hline Common Dummy & + & $\begin{array}{c}0.019 * * * \\
(3.451)\end{array}$ & & & \\
\hline No. Common Firms & + & & $\begin{array}{c}0.015 * * * \\
(3.468)\end{array}$ & & \\
\hline MV Common Firms & + & & & $\begin{array}{c}0.005 * * * \\
(4.336)\end{array}$ & \\
\hline No. Common Investors & + & & & & $\begin{array}{c}0.030 * * * \\
(3.414)\end{array}$ \\
\hline Institutional Ownership & & $\begin{array}{c}0.103 * * * \\
(3.659)\end{array}$ & $\begin{array}{c}0.097 * * * \\
(3.590)\end{array}$ & $\begin{array}{c}0.098 * * * \\
(3.577)\end{array}$ & $\begin{array}{c}0.100 * * * \\
(3.857)\end{array}$ \\
\hline Blockholder Ownership & & $\begin{array}{c}-0.143 * * * \\
(-4.301)\end{array}$ & $\begin{array}{c}-0.146^{* * *} \\
(-4.285)\end{array}$ & $\begin{array}{c}-0.145 * * * \\
(-4.318)\end{array}$ & $\begin{array}{c}-0.130 * * * \\
(-3.732)\end{array}$ \\
\hline Common Ownership DiffInd & & $\begin{array}{c}-0.036 * * * \\
(-3.941)\end{array}$ & $\begin{array}{c}-0.007 * * * \\
(-3.577)\end{array}$ & $\begin{array}{c}-0.004 * * * \\
(-4.071)\end{array}$ & $\begin{array}{c}-0.033 * * * \\
(-3.908)\end{array}$ \\
\hline Loss & & $\begin{array}{c}-0.033 * * * \\
(-6.452)\end{array}$ & $\begin{array}{c}-0.033^{* * *} \\
(-6.462)\end{array}$ & $\begin{array}{c}-0.033 * * * \\
(-6.477)\end{array}$ & $\begin{array}{c}-0.033 * * * \\
(-6.463)\end{array}$ \\
\hline$R O A$ & & $\begin{array}{c}0.055^{* * *} \\
(3.307)\end{array}$ & $\begin{array}{c}0.054 * * * \\
(3.268)\end{array}$ & $\begin{array}{c}0.054 * * * \\
(3.265)\end{array}$ & $\begin{array}{c}0.054 * * * \\
(3.259)\end{array}$ \\
\hline $\operatorname{BigN}$ & & $\begin{array}{c}0.027 * * \\
(2.334)\end{array}$ & $\begin{array}{c}0.028 * * \\
(2.405)\end{array}$ & $\begin{array}{c}0.028 * * \\
(2.369)\end{array}$ & $\begin{array}{c}0.028 * * \\
(2.362)\end{array}$ \\
\hline Analysts & & $\begin{array}{c}0.016^{* * *} \\
(2.942)\end{array}$ & $\begin{array}{c}0.016^{* * *} \\
(2.925)\end{array}$ & $\begin{array}{c}0.016 * * \\
(2.915)\end{array}$ & $\begin{array}{c}0.015 * * \\
(2.842)\end{array}$ \\
\hline Earnings Increase & & $\begin{array}{c}-0.018 * * * \\
(-5.082)\end{array}$ & $\begin{array}{c}-0.018 * * * \\
(-5.073)\end{array}$ & $\begin{array}{c}-0.018 * * * \\
(-5.064)\end{array}$ & $\begin{array}{c}-0.018 * * * \\
(-5.050)\end{array}$ \\
\hline Assets & & $\begin{array}{c}0.048 * * * \\
(8.388)\end{array}$ & $\begin{array}{c}0.048 * * * \\
(8.444)\end{array}$ & $\begin{array}{c}0.048^{* * *} \\
(8.394)\end{array}$ & $\begin{array}{c}0.048 * * * \\
(8.338)\end{array}$ \\
\hline$M T B$ & & $\begin{array}{c}0.010 * * * \\
(4.054)\end{array}$ & $\begin{array}{c}0.010 * * * \\
(4.019)\end{array}$ & $\begin{array}{c}0.010 * * * \\
(4.057)\end{array}$ & $\begin{array}{c}0.009 * * * \\
(4.037)\end{array}$ \\
\hline Leverage & & $\begin{array}{c}-0.039 * * \\
(-2.306)\end{array}$ & $\begin{array}{c}-0.040 * * \\
(-2.349)\end{array}$ & $\begin{array}{c}-0.040 * * \\
(-2.347)\end{array}$ & $\begin{array}{c}-0.039 * * \\
(-2.306)\end{array}$ \\
\hline No. Stoppers & & $\begin{array}{c}0.185 * * * \\
(9.735)\end{array}$ & $\begin{array}{c}0.184 * * * \\
(9.720)\end{array}$ & $\begin{array}{c}0.184 * * * \\
(9.722)\end{array}$ & $\begin{array}{c}0.184 * * * \\
(9.779)\end{array}$ \\
\hline Stdev. Earn & & $\begin{array}{c}-0.093 * * * \\
(-3.466)\end{array}$ & $\begin{array}{c}-0.092 * * * \\
(-3.431)\end{array}$ & $\begin{array}{c}-0.092 * * * \\
(-3.425)\end{array}$ & $\begin{array}{c}-0.091 * * * \\
(-3.417)\end{array}$ \\
\hline Sales growth & & $\begin{array}{c}0.007 \\
(1.627)\end{array}$ & $\begin{array}{c}0.007 \\
(1.580)\end{array}$ & $\begin{array}{c}0.007 \\
(1.587)\end{array}$ & $\begin{array}{c}0.007 \\
(1.645)\end{array}$ \\
\hline No. of Observations & & 54,541 & 54,541 & 54,541 & 54,541 \\
\hline Adj. R-Squared & & 0.609 & 0.609 & 0.609 & 0.609 \\
\hline Firm \& Year $\times$ Industry Indicators & & Yes & Yes & Yes & Yes \\
\hline SE Clustered by Firm and Year & & Yes & Yes & Yes & Yes \\
\hline
\end{tabular}




\section{Table 4 (continued)}

Panel B: Using Earnings Forecast Freq as the proxy for voluntary disclosure

(1) (2) (3)

(4)

\begin{tabular}{|c|c|c|c|c|c|}
\hline Dependent Variable: & Pr. Sign & \multicolumn{4}{|c|}{ Earnings Forecast Freq } \\
\hline Common Dummy & + & $\begin{array}{c}0.039 * * * \\
(3.403)\end{array}$ & & & \\
\hline No. Common Firms & + & & $\begin{array}{c}0.023 * * * \\
(3.438)\end{array}$ & & \\
\hline MV Common Firms & + & & & $\begin{array}{c}0.010 * * * \\
(5.133)\end{array}$ & \\
\hline No. Common Investors & + & & & & $\begin{array}{c}0.053 * * * \\
(3.644)\end{array}$ \\
\hline Institutional Ownership & & $\begin{array}{c}0.208 * * * \\
(4.278)\end{array}$ & $\begin{array}{c}0.192 * * * \\
(4.105)\end{array}$ & $\begin{array}{c}0.196^{* * *} \\
(4.156)\end{array}$ & $\begin{array}{c}0.200 * * * \\
(4.347)\end{array}$ \\
\hline Blockholder Ownership & & $\begin{array}{c}-0.310^{* * *} \\
(-5.321)\end{array}$ & $\begin{array}{c}-0.317 * * * \\
(-5.304)\end{array}$ & $\begin{array}{c}-0.314 * * * \\
(-5.369)\end{array}$ & $\begin{array}{c}-0.290 * * * \\
(-4.957)\end{array}$ \\
\hline Common Ownership DiffInd & & $\begin{array}{c}-0.068 * * * \\
(-4.291)\end{array}$ & $\begin{array}{c}-0.010 * * * \\
(-3.349)\end{array}$ & $\begin{array}{c}-0.007 * * * \\
(-4.688)\end{array}$ & $\begin{array}{c}-0.056 * * * \\
(-4.351)\end{array}$ \\
\hline Loss & & $\begin{array}{c}-0.065 * * * \\
(-6.960)\end{array}$ & $\begin{array}{c}-0.065 * * * \\
(-7.004)\end{array}$ & $\begin{array}{c}-0.065 * * * \\
(-6.996)\end{array}$ & $\begin{array}{c}-0.065 * * * \\
(-6.961)\end{array}$ \\
\hline$R O A$ & & $\begin{array}{l}0.058 * \\
(1.833)\end{array}$ & $\begin{array}{l}0.056^{*} \\
(1.796)\end{array}$ & $\begin{array}{l}0.056^{*} \\
(1.793)\end{array}$ & $\begin{array}{l}0.056^{*} \\
(1.789)\end{array}$ \\
\hline $\operatorname{BigN}$ & & $\begin{array}{c}0.081 * * * \\
(3.670)\end{array}$ & $\begin{array}{c}0.083 * * * \\
(3.704)\end{array}$ & $\begin{array}{c}0.082 * * * \\
(3.675)\end{array}$ & $\begin{array}{c}0.082^{* * *} \\
(3.672)\end{array}$ \\
\hline Analysts & & $\begin{array}{c}0.024 * * * \\
(3.062)\end{array}$ & $\begin{array}{c}0.023 * * * \\
(3.021)\end{array}$ & $\begin{array}{c}0.023 * * * \\
(3.027)\end{array}$ & $\begin{array}{c}0.022 * * \\
(2.914)\end{array}$ \\
\hline Earnings Increase & & $\begin{array}{c}-0.017 * * * \\
(-3.561)\end{array}$ & $\begin{array}{c}-0.017 * * * \\
(-3.550)\end{array}$ & $\begin{array}{c}-0.017 * * * \\
(-3.547)\end{array}$ & $\begin{array}{c}-0.017 * * * \\
(-3.530)\end{array}$ \\
\hline Assets & & $\begin{array}{c}0.082 * * * \\
(8.237)\end{array}$ & $\begin{array}{c}0.083 * * * \\
(8.302)\end{array}$ & $\begin{array}{c}0.082 * * * \\
(8.239)\end{array}$ & $\begin{array}{c}0.082 * * * \\
(8.226)\end{array}$ \\
\hline$M T B$ & & $\begin{array}{c}0.011 * * * \\
(2.967)\end{array}$ & $\begin{array}{c}0.011 * * * \\
(2.941)\end{array}$ & $\begin{array}{c}0.011 * * * \\
(2.950)\end{array}$ & $\begin{array}{c}0.011 * * * \\
(2.949)\end{array}$ \\
\hline Leverage & & $\begin{array}{c}-0.036 \\
(-1.313)\end{array}$ & $\begin{array}{c}-0.037 \\
(-1.360)\end{array}$ & $\begin{array}{c}-0.037 \\
(-1.362)\end{array}$ & $\begin{array}{c}-0.036 \\
(-1.318)\end{array}$ \\
\hline No. Stoppers & & $\begin{array}{c}0.331 * * * \\
(13.746)\end{array}$ & $\begin{array}{c}0.330 * * * \\
(13.720)\end{array}$ & $\begin{array}{c}0.330 * * * \\
(13.724)\end{array}$ & $\begin{array}{c}0.330 * * * \\
(13.808)\end{array}$ \\
\hline Stdev. Earn & & $\begin{array}{c}-0.148 * * * \\
(-3.410)\end{array}$ & $\begin{array}{c}-0.147 * * * \\
(-3.354)\end{array}$ & $\begin{array}{c}-0.146^{* * * *} \\
(-3.348)\end{array}$ & $\begin{array}{c}-0.146^{* * * *} \\
(-3.342)\end{array}$ \\
\hline Sales growth & & $\begin{array}{l}0.014 * \\
(2.042)\end{array}$ & $\begin{array}{l}0.014 * \\
(1.992)\end{array}$ & $\begin{array}{l}0.014 * \\
(2.016)\end{array}$ & $\begin{array}{l}0.015^{*} \\
(2.053)\end{array}$ \\
\hline No. of Observations & & 54,541 & 54,541 & 54,541 & 54,541 \\
\hline Adj. R-Squared & & 0.667 & 0.667 & 0.667 & 0.667 \\
\hline Firm \& Year $\times$ Industry Indicators & & Yes & Yes & Yes & Yes \\
\hline SE Clustered by Firm and Year & & Yes & Yes & Yes & Yes \\
\hline
\end{tabular}


Table 5

Effect of common ownership on management capital expenditure forecasts

This table presents the results from regressing voluntary disclosure on lagged common ownership and other determinants of disclosure. In Panel A, the proxy for voluntary disclosure is Capex Guide, which is a dummy variable equal to one if the firm issues at least one capital expenditure forecast during a fiscal year, and in Panel B, the proxy for voluntary disclosure is Capex Forecast Freq, which is the natural log of one plus the number of capital expenditure forecasts issued during the fiscal year. Continuous variables are winsorized at the $1 \%$ and $99 \%$ levels and are defined in the Variable Appendix. ${ }^{* * *, * * *}$ indicate statistical significance at the $10 \%, 5 \%$, and 1\% levels, respectively, using a two-tailed $t$-test.

Panel A: Using Capex Guide as the proxy for voluntary disclosure

\begin{tabular}{|c|c|c|c|c|c|}
\hline \multirow[b]{2}{*}{ Dependent Variable: } & \multirow[b]{2}{*}{ Pr. Sign } & (1) & (2) & (3) & (4) \\
\hline & & \multicolumn{4}{|c|}{ Capex Guide } \\
\hline Common Dummy & + & $\begin{array}{c}0.033 * * * \\
(4.589)\end{array}$ & & & \\
\hline No. Common Firms & + & & $\begin{array}{c}0.015 * * * \\
(4.935)\end{array}$ & & \\
\hline MV Common Firms & + & & & $\begin{array}{c}0.007 * * * \\
(5.613)\end{array}$ & \\
\hline No. Common Investors & + & & & & $\begin{array}{c}0.040 * * * \\
(4.914)\end{array}$ \\
\hline Institutional Ownership & & $\begin{array}{c}0.091 * * * \\
(3.637)\end{array}$ & $\begin{array}{c}0.065 * * \\
(2.480)\end{array}$ & $\begin{array}{l}0.071 * * \\
(2.726)\end{array}$ & $\begin{array}{c}0.073 * * \\
(2.773)\end{array}$ \\
\hline Blockholder Ownership & & $\begin{array}{c}-0.057 \\
(-1.631)\end{array}$ & $\begin{array}{l}-0.069 * \\
(-2.006)\end{array}$ & $\begin{array}{l}-0.064 * \\
(-1.839)\end{array}$ & $\begin{array}{l}-0.063 * \\
(-1.871)\end{array}$ \\
\hline Common Ownership DiffInd & & $\begin{array}{c}-0.049 * * * \\
(-5.667)\end{array}$ & $\begin{array}{l}-0.003 * \\
(-1.812)\end{array}$ & $\begin{array}{c}-0.003 * * * \\
(-3.704)\end{array}$ & $\begin{array}{c}-0.023 * * \\
(-2.819)\end{array}$ \\
\hline Loss & & $\begin{array}{c}-0.005 \\
(-0.874)\end{array}$ & $\begin{array}{c}-0.005 \\
(-0.926)\end{array}$ & $\begin{array}{c}-0.005 \\
(-0.925)\end{array}$ & $\begin{array}{c}-0.005 \\
(-0.923)\end{array}$ \\
\hline$R O A$ & & $\begin{array}{c}-0.019 \\
(-1.215)\end{array}$ & $\begin{array}{c}-0.020 \\
(-1.277)\end{array}$ & $\begin{array}{c}-0.020 \\
(-1.282)\end{array}$ & $\begin{array}{c}-0.019 \\
(-1.250)\end{array}$ \\
\hline $\operatorname{Big} N$ & & $\begin{array}{c}0.099 * * * \\
(4.619)\end{array}$ & $\begin{array}{c}0.101^{* * * *} \\
(4.609)\end{array}$ & $\begin{array}{c}0.100 * * * \\
(4.595)\end{array}$ & $\begin{array}{c}0.100 * * * \\
(4.626)\end{array}$ \\
\hline Analysts & & $\begin{array}{c}0.002 \\
(0.547)\end{array}$ & $\begin{array}{c}0.002 \\
(0.448)\end{array}$ & $\begin{array}{c}0.002 \\
(0.436)\end{array}$ & $\begin{array}{c}0.002 \\
(0.386)\end{array}$ \\
\hline Earnings Increase & & $\begin{array}{c}-0.001 \\
(-0.238)\end{array}$ & $\begin{array}{c}-0.001 \\
(-0.248)\end{array}$ & $\begin{array}{c}-0.001 \\
(-0.224)\end{array}$ & $\begin{array}{c}-0.001 \\
(-0.255)\end{array}$ \\
\hline Assets & & $\begin{array}{c}0.026 * * * \\
(4.881)\end{array}$ & $\begin{array}{c}0.026 * * * \\
(4.978)\end{array}$ & $\begin{array}{c}0.026^{* * *} \\
(4.939)\end{array}$ & $\begin{array}{c}0.026 * * * \\
(4.952)\end{array}$ \\
\hline$M T B$ & & $\begin{array}{l}-0.004 * \\
(-1.990)\end{array}$ & $\begin{array}{l}-0.004 * \\
(-1.943)\end{array}$ & $\begin{array}{l}-0.004^{*} \\
(-1.980)\end{array}$ & $\begin{array}{l}-0.004^{*} \\
(-1.932)\end{array}$ \\
\hline Leverage & & $\begin{array}{l}0.036^{*} \\
(2.025)\end{array}$ & $\begin{array}{l}0.035^{*} \\
(1.973)\end{array}$ & $\begin{array}{l}0.035^{*} \\
(1.975)\end{array}$ & $\begin{array}{l}0.036^{*} \\
(2.020)\end{array}$ \\
\hline No. Stoppers & & $\begin{array}{c}-0.002 \\
(-0.286)\end{array}$ & $\begin{array}{c}-0.002 \\
(-0.309)\end{array}$ & $\begin{array}{c}-0.003 \\
(-0.351)\end{array}$ & $\begin{array}{c}-0.002 \\
(-0.307)\end{array}$ \\
\hline Stdev. Earn & & $\begin{array}{c}0.009 \\
(0.389)\end{array}$ & $\begin{array}{c}0.012 \\
(0.498)\end{array}$ & $\begin{array}{c}0.012 \\
(0.493)\end{array}$ & $\begin{array}{c}0.012 \\
(0.507)\end{array}$ \\
\hline Sales growth & & $\begin{array}{l}-0.011 * * \\
(-2.249)\end{array}$ & $\begin{array}{c}-0.011 * * \\
(-2.321)\end{array}$ & $\begin{array}{c}-0.011 * * \\
(-2.297)\end{array}$ & $\begin{array}{c}-0.011 * * \\
(-2.276)\end{array}$ \\
\hline No. of Observations & & 54,541 & 54,541 & 54,541 & 54,541 \\
\hline Adj. R-Squared & & 0.584 & 0.584 & 0.584 & 0.584 \\
\hline Firm \& Year $\times$ Industry Indicators & & Yes & Yes & Yes & Yes \\
\hline SE Clustered by Firm and Year & & Yes & Yes & Yes & Yes \\
\hline
\end{tabular}




\section{Table 5 (continued)}

Panel B: Using Capex Forecast Freq as the proxy for voluntary disclosure

(1) (2)

(3)

(4)

Dependent Variable:

Pr. Sign

Capex Forecast Freq

\begin{tabular}{|c|c|c|c|c|c|}
\hline Common Dummy & + & $\begin{array}{c}0.042 * * * \\
(4.060)\end{array}$ & & & \\
\hline No. Common Firms & + & & $\begin{array}{c}0.021 * * * \\
(5.690)\end{array}$ & & \\
\hline MV Common Firms & + & & & $\begin{array}{c}0.010 * * * \\
(5.901)\end{array}$ & \\
\hline No. Common Investors & + & & & & $\begin{array}{c}0.056 * * * \\
(5.486)\end{array}$ \\
\hline Institutional Ownership & & $\begin{array}{c}0.104 * * \\
(2.582)\end{array}$ & $\begin{array}{l}0.069 * \\
(1.675)\end{array}$ & $\begin{array}{l}0.079 * \\
(1.900)\end{array}$ & $\begin{array}{l}0.080 * \\
(1.940)\end{array}$ \\
\hline Blockholder Ownership & & $\begin{array}{l}-0.096^{*} \\
(-1.873)\end{array}$ & $\begin{array}{l}-0.112 * * \\
(-2.237)\end{array}$ & $\begin{array}{l}-0.105^{*} \\
(-2.072)\end{array}$ & $\begin{array}{c}-0.103 * * \\
(-2.209)\end{array}$ \\
\hline Common Ownership DiffInd & & $\begin{array}{c}-0.065 * * * \\
(-5.293)\end{array}$ & $\begin{array}{l}-0.004 * \\
(-1.688)\end{array}$ & $\begin{array}{c}-0.005 * * * \\
(-3.942)\end{array}$ & $\begin{array}{c}-0.034 * * * \\
(-3.334)\end{array}$ \\
\hline Loss & & $\begin{array}{c}-0.006 \\
(-0.769)\end{array}$ & $\begin{array}{c}-0.007 \\
(-0.816)\end{array}$ & $\begin{array}{c}-0.007 \\
(-0.813)\end{array}$ & $\begin{array}{c}-0.007 \\
(-0.813)\end{array}$ \\
\hline$R O A$ & & $\begin{array}{c}-0.026 \\
(-1.365)\end{array}$ & $\begin{array}{c}-0.027 \\
(-1.426)\end{array}$ & $\begin{array}{c}-0.027 \\
(-1.432)\end{array}$ & $\begin{array}{c}-0.027 \\
(-1.388)\end{array}$ \\
\hline $\operatorname{BigN}$ & & $\begin{array}{c}0.150 * * * \\
(5.210)\end{array}$ & $\begin{array}{c}0.151 * * * \\
(5.189)\end{array}$ & $\begin{array}{c}0.150 * * * \\
(5.170)\end{array}$ & $\begin{array}{c}0.151 * * * \\
(5.196)\end{array}$ \\
\hline Analysts & & $\begin{array}{l}0.014^{*} \\
(1.951)\end{array}$ & $\begin{array}{l}0.014 * \\
(1.872)\end{array}$ & $\begin{array}{c}0.014 * \\
(1.867)\end{array}$ & $\begin{array}{c}0.013 * \\
(1.804)\end{array}$ \\
\hline Earnings Increase & & $\begin{array}{c}-0.002 \\
(-0.356)\end{array}$ & $\begin{array}{c}-0.002 \\
(-0.372)\end{array}$ & $\begin{array}{c}-0.002 \\
(-0.343)\end{array}$ & $\begin{array}{c}-0.002 \\
(-0.375)\end{array}$ \\
\hline Assets & & $\begin{array}{c}0.037 * * * \\
(4.098)\end{array}$ & $\begin{array}{c}0.037 * * * \\
(4.168)\end{array}$ & $\begin{array}{c}0.037 * * * \\
(4.130)\end{array}$ & $\begin{array}{c}0.037 * * * \\
(4.147)\end{array}$ \\
\hline$M T B$ & & $\begin{array}{l}-0.006^{*} \\
(-2.028)\end{array}$ & $\begin{array}{l}-0.006^{*} \\
(-1.982)\end{array}$ & $\begin{array}{l}-0.006^{*} \\
(-2.024)\end{array}$ & $\begin{array}{l}-0.006 * \\
(-1.976)\end{array}$ \\
\hline Leverage & & $\begin{array}{c}0.061 * * \\
(2.512)\end{array}$ & $\begin{array}{c}0.060 * * \\
(2.460)\end{array}$ & $\begin{array}{c}0.060 * * \\
(2.463)\end{array}$ & $\begin{array}{c}0.061 * * \\
(2.512)\end{array}$ \\
\hline No. Stoppers & & $\begin{array}{c}-0.008 \\
(-0.837)\end{array}$ & $\begin{array}{c}-0.008 \\
(-0.882)\end{array}$ & $\begin{array}{c}-0.008 \\
(-0.927)\end{array}$ & $\begin{array}{c}-0.008 \\
(-0.884)\end{array}$ \\
\hline Stdev. Earn & & $\begin{array}{c}0.025 \\
(0.739)\end{array}$ & $\begin{array}{c}0.029 \\
(0.844)\end{array}$ & $\begin{array}{c}0.028 \\
(0.839)\end{array}$ & $\begin{array}{c}0.029 \\
(0.851)\end{array}$ \\
\hline Sales growth & & $\begin{array}{l}-0.014 * \\
(-1.974)\end{array}$ & $\begin{array}{l}-0.014^{*} \\
(-2.061)\end{array}$ & $\begin{array}{l}-0.014 * \\
(-2.037)\end{array}$ & $\begin{array}{l}-0.014^{*} \\
(-2.005)\end{array}$ \\
\hline No. of Observations & & 54,541 & 54,541 & 54,541 & 54,541 \\
\hline Adj. R-Squared & & 0.637 & 0.637 & 0.637 & 0.637 \\
\hline Firm \& Year $\times$ Industry Indicators & & Yes & Yes & Yes & Yes \\
\hline SE Clustered by Firm and Year & & Yes & Yes & Yes & Yes \\
\hline
\end{tabular}


Table 6

Effect of common ownership on redactions from material contracts

This table presents the results from regressing voluntary disclosure on lagged common ownership and other determinants of disclosure. The proxy for voluntary disclosure is \%Redaction, which is a ratio of the number of fillings with redacted disclosures to the total number of fillings with at least one material contracts filed with the SEC in a fiscal year. All continuous variables are winsorized at the $1 \%$ and $99 \%$ levels and are defined in the Variable Appendix. All specifications include firm and industry $\times$ year fixed effects. Standard errors are clustered at the year and firm level. ${ }^{* * *, * * *}$ indicate statistical significance at the $10 \%, 5 \%$, and $1 \%$ levels, respectively, using a two-tailed $t$-test.

(1)

(2)

(3)

(4)

\begin{tabular}{|c|c|c|c|c|c|}
\hline Dependent Variable: & Pr. Sign & & $\% K$ & ion & \\
\hline Common Dummy & $-/ ?$ & $\begin{array}{c}-0.002 \\
(-0.853)\end{array}$ & & & \\
\hline No. Common Firms & $-/ ?$ & & $\begin{array}{c}0.001 \\
(0.656)\end{array}$ & & \\
\hline MV Common Firms & $-/ ?$ & & & $\begin{array}{c}-0.000 \\
(-1.015)\end{array}$ & \\
\hline No. Common Investors & $-/ ?$ & & & & $\begin{array}{c}-0.001 \\
(-0.439)\end{array}$ \\
\hline Institutional Ownership & & $\begin{array}{c}-0.012 \\
(-1.355)\end{array}$ & $\begin{array}{c}-0.010 \\
(-1.131)\end{array}$ & $\begin{array}{c}-0.011 \\
(-1.233)\end{array}$ & $\begin{array}{c}-0.012 \\
(-1.394)\end{array}$ \\
\hline Blockholder Ownership & & $\begin{array}{c}0.005 \\
(0.544)\end{array}$ & $\begin{array}{c}0.005 \\
(0.547)\end{array}$ & $\begin{array}{c}0.005 \\
(0.562)\end{array}$ & $\begin{array}{c}0.003 \\
(0.319)\end{array}$ \\
\hline Common Ownership DiffInd & & $\begin{array}{c}0.004 \\
(1.206)\end{array}$ & $\begin{array}{c}-0.000 \\
(-0.414)\end{array}$ & $\begin{array}{c}0.000 \\
(1.150)\end{array}$ & $\begin{array}{c}0.003 \\
(1.070)\end{array}$ \\
\hline Loss & & $\begin{array}{c}0.002 \\
(0.519)\end{array}$ & $\begin{array}{c}0.002 \\
(0.524)\end{array}$ & $\begin{array}{c}0.002 \\
(0.523)\end{array}$ & $\begin{array}{c}0.002 \\
(0.521)\end{array}$ \\
\hline$R O A$ & & $\begin{array}{c}0.001 \\
(0.103)\end{array}$ & $\begin{array}{c}0.001 \\
(0.110)\end{array}$ & $\begin{array}{c}0.001 \\
(0.109)\end{array}$ & $\begin{array}{c}0.001 \\
(0.116)\end{array}$ \\
\hline $\operatorname{BigN}$ & & $\begin{array}{c}0.003 \\
(0.871)\end{array}$ & $\begin{array}{c}0.003 \\
(0.813)\end{array}$ & $\begin{array}{c}0.003 \\
(0.844)\end{array}$ & $\begin{array}{c}0.003 \\
(0.838)\end{array}$ \\
\hline Analysts & & $\begin{array}{c}-0.001 \\
(-0.631)\end{array}$ & $\begin{array}{c}-0.001 \\
(-0.543)\end{array}$ & $\begin{array}{c}-0.001 \\
(-0.602)\end{array}$ & $\begin{array}{c}-0.001 \\
(-0.551)\end{array}$ \\
\hline Earnings Increase & & $\begin{array}{c}-0.000 \\
(-0.009)\end{array}$ & $\begin{array}{c}-0.000 \\
(-0.013)\end{array}$ & $\begin{array}{c}-0.000 \\
(-0.012)\end{array}$ & $\begin{array}{c}-0.000 \\
(-0.032)\end{array}$ \\
\hline Assets & & $\begin{array}{c}-0.000 \\
(-0.030)\end{array}$ & $\begin{array}{c}-0.000 \\
(-0.100)\end{array}$ & $\begin{array}{c}-0.000 \\
(-0.054)\end{array}$ & $\begin{array}{c}-0.000 \\
(-0.051)\end{array}$ \\
\hline$M T B$ & & $\begin{array}{c}0.001 \\
(0.550)\end{array}$ & $\begin{array}{c}0.000 \\
(0.512)\end{array}$ & $\begin{array}{c}0.000 \\
(0.543)\end{array}$ & $\begin{array}{c}0.001 \\
(0.561)\end{array}$ \\
\hline Leverage & & $\begin{array}{c}-0.012 * * \\
(-2.232)\end{array}$ & $\begin{array}{c}-0.012 * * \\
(-2.220)\end{array}$ & $\begin{array}{c}-0.012 * * \\
(-2.220)\end{array}$ & $\begin{array}{c}-0.012 * * \\
(-2.230)\end{array}$ \\
\hline Debt Issue & & $\begin{array}{c}0.001 \\
(0.626)\end{array}$ & $\begin{array}{c}0.001 \\
(0.623)\end{array}$ & $\begin{array}{c}0.001 \\
(0.628)\end{array}$ & $\begin{array}{c}0.001 \\
(0.625)\end{array}$ \\
\hline Equity Issue & & $\begin{array}{c}0.002 \\
(0.671)\end{array}$ & $\begin{array}{c}0.002 \\
(0.685)\end{array}$ & $\begin{array}{c}0.002 \\
(0.676)\end{array}$ & $\begin{array}{c}0.002 \\
(0.704)\end{array}$ \\
\hline Sales growth & & $\begin{array}{c}0.009 * * * \\
(3.607)\end{array}$ & $\begin{array}{c}0.009 * * * \\
(3.608)\end{array}$ & $\begin{array}{c}0.009 * * * \\
(3.610)\end{array}$ & $\begin{array}{c}0.009 * * * \\
(3.604)\end{array}$ \\
\hline No. of Observations & & 66,455 & 66,455 & 66,455 & 66,455 \\
\hline Adj. R-Squared & & 0.301 & 0.301 & 0.301 & 0.301 \\
\hline Firm \& Year $\times$ Industry Indicators & & Yes & Yes & Yes & Yes \\
\hline SE Clustered by Firm and Year & & Yes & Yes & Yes & Yes \\
\hline
\end{tabular}




\section{Table 7}

Degree of industry-level common ownership: Cross-sectional variation in the effect of common ownership on disclosure

This table presents the results from regressing voluntary disclosure on lagged common ownership, interaction terms between common ownership and an indicator for the industries with higher than average common ownership (High Industry Common Own), and other determinants of disclosure. Panels A, B, and C report results when management earnings forecasts, management capital expenditure forecasts, and redactions from disclosure of material contracts are proxies for voluntary disclosure, respectively. All continuous variables are winsorized at the 1\% and $99 \%$ levels and are defined in the Variable Appendix. All specifications include firm and industry $\times$ year fixed effects. Standard errors are clustered at the year and firm level. ${ }^{* * * * * * *}$ indicate statistical significance at the $10 \%, 5 \%$, and $1 \%$ levels, respectively, using a two-tailed $t$-test.

Panel A: Using earnings forecasts as the proxy for voluntary disclosure

\begin{tabular}{|c|c|c|c|c|c|c|c|c|}
\hline \multirow[b]{2}{*}{ Dependent Variable: } & (1) & (2) & (3) & (4) & (5) & (6) & (7) & (8) \\
\hline & \multicolumn{4}{|c|}{ Earnings Guide } & \multicolumn{4}{|c|}{ Earnings Forecast Freq } \\
\hline Common Dummy $\times$ High Industry Common Own & $\begin{array}{l}0.012^{*} \\
(1.682)\end{array}$ & & & & $\begin{array}{c}0.025 * * \\
(2.509)\end{array}$ & & & \\
\hline Common Dummy & $\begin{array}{c}0.018 * * * \\
(3.261)\end{array}$ & & & & $\begin{array}{c}0.036 * * * \\
(3.282)\end{array}$ & & & \\
\hline No. Common Firms $\times$ High Industry Common Own & & $\begin{array}{c}0.004 \\
(1.036)\end{array}$ & & & & $\begin{array}{c}0.009 \\
(1.499)\end{array}$ & & \\
\hline No. Common Firms & & $\begin{array}{c}0.014 * * * \\
(3.434)\end{array}$ & & & & $\begin{array}{c}0.021 * * * \\
(3.349)\end{array}$ & & \\
\hline MV Common Firms $\times$ High Industry Common Own & & & $\begin{array}{c}0.002 \\
(1.472)\end{array}$ & & & & $\begin{array}{c}0.004 * * \\
(2.167)\end{array}$ & \\
\hline MV Common Firms & & & $\begin{array}{c}0.005 * * * \\
(4.072)\end{array}$ & & & & $\begin{array}{c}0.010 * * * \\
(4.977)\end{array}$ & \\
\hline No. Common Investors $\times$ High Industry Common Own & & & & $\begin{array}{l}0.015^{*} \\
(1.922)\end{array}$ & & & & $\begin{array}{c}0.033 * * \\
(2.571)\end{array}$ \\
\hline No. Common Investors & & & & $\begin{array}{c}0.026 * * * \\
(3.175)\end{array}$ & & & & $\begin{array}{c}0.045 * * * \\
(3.297)\end{array}$ \\
\hline No. of Observations & 54,541 & 54,541 & 54,541 & 54,541 & 54,541 & 54,541 & 54,541 & 54,541 \\
\hline Adj. R-Squared & 0.609 & 0.609 & 0.609 & 0.609 & 0.667 & 0.667 & 0.667 & 0.667 \\
\hline Control Variables Included & Yes & Yes & Yes & Yes & Yes & Yes & Yes & Yes \\
\hline Firm \& Year $\times$ Industry Indicators & Yes & Yes & Yes & Yes & Yes & Yes & Yes & Yes \\
\hline SE Clustered by Firm and Year & Yes & Yes & Yes & Yes & Yes & Yes & Yes & Yes \\
\hline
\end{tabular}




\section{Table 7 (continued)}

Panel B: Using capital expenditure forecasts as the proxy for voluntary disclosure

\begin{tabular}{|c|c|c|c|c|c|c|c|c|}
\hline \multirow[b]{2}{*}{ Dependent Variable: } & (1) & $(2)$ & (3) & (4) & (5) & (6) & $(7)$ & (8) \\
\hline & \multicolumn{4}{|c|}{ Capex Guide } & \multicolumn{4}{|c|}{ Capex Forecast Freq } \\
\hline Common Dummy $\times$ High Industry Common Own & $\begin{array}{c}0.020 * * \\
(2.893)\end{array}$ & & & & $\begin{array}{c}0.023 * * \\
(2.174)\end{array}$ & & & \\
\hline Common Dummy & $\begin{array}{c}0.030 * * * \\
(4.471)\end{array}$ & & & & $\begin{array}{c}0.040 * * * \\
(3.989)\end{array}$ & & & \\
\hline No. Common Firms $\times$ High Industry Common Own & & $\begin{array}{c}0.008 * * \\
(2.665)\end{array}$ & & & & $\begin{array}{c}0.015 * * * \\
(3.684)\end{array}$ & & \\
\hline No. Common Firms & & $\begin{array}{c}0.013 * * * \\
(4.626)\end{array}$ & & & & $\begin{array}{c}0.017 * * * \\
(5.059)\end{array}$ & & \\
\hline MV Common Firms $\times$ High Industry Common Own & & & $\begin{array}{c}0.004 * * * \\
(3.132)\end{array}$ & & & & $\begin{array}{c}0.006^{* * *} \\
(3.444)\end{array}$ & \\
\hline MV Common Firms & & & $\begin{array}{c}0.006 * * * \\
(5.503)\end{array}$ & & & & $\begin{array}{c}0.009 * * * \\
(5.852)\end{array}$ & \\
\hline No. Common Investors $\times$ High Industry Common Own & & & & $\begin{array}{c}0.030 * * * \\
(4.568)\end{array}$ & & & & $\begin{array}{c}0.044 * * * \\
(4.484)\end{array}$ \\
\hline No. Common Investors & & & & $\begin{array}{c}0.033 * * * \\
(4.473)\end{array}$ & & & & $\begin{array}{c}0.046^{* * *} \\
(5.119)\end{array}$ \\
\hline No. of Observations & 54,541 & 54,541 & 54,541 & 54,541 & 54,541 & 54,541 & 54,541 & 54,541 \\
\hline Adj. R-Squared & 0.584 & 0.584 & 0.584 & 0.584 & 0.637 & 0.637 & 0.637 & 0.637 \\
\hline Control Variables Included & Yes & Yes & Yes & Yes & Yes & Yes & Yes & Yes \\
\hline Firm \& Year $\times$ Industry Indicators & Yes & Yes & Yes & Yes & Yes & Yes & Yes & Yes \\
\hline SE Clustered by Firm and Year & Yes & Yes & Yes & Yes & Yes & Yes & Yes & Yes \\
\hline
\end{tabular}




\section{Table 7 (continued)}

Panel C: Using redactions from material contracts filed with the SEC as the proxy for voluntary disclosure

(1)

Dependent Variable:

\begin{tabular}{lc}
\hline \hline Common Dummy $\times$ High Industry Common Own & $-0.007 * * *$ \\
Common Dummy & $(-2.977)$ \\
& -0.001 \\
& $(-0.540)$
\end{tabular}

No. Common Firms $\times$ High Industry Common Own

No. Common Firms

MV Common Firms $\times$ High Industry Common Own

MV Common Firms

No. Common Investors $\times$ High Industry Common Own

(2)

$\%$ Redaction

(3)

(4)

4)

No. Common Investors

$-0.001$

$(-1.201)$

0.001

(0.974)

$-0.001^{*}$

$(-1.671)$

$-0.000$

$(-0.738)$

$-0.005^{*}$

$(-1.801)$

$-0.000$

$(-0.040)$

No. of Observations

66,455

66,455

66,455

Adj. R-Squared

Control Variables Included

0.301

0.301

66,455

Yes

Yes

0.301

0.301

Firm \& Year $\times$ Industry Indicators

Yes

Yes

Yes

Yes

SE Clustered by Firm and Year
Yes

Yes
Yes

Yes Yes




\section{Table 8}

Difference-in-Differences analyses of the effect of common ownership on disclosure in response to exogenous changes in analyst coverage of peer firms

This table reports difference-in-difference results examining the effects of exogenous shock to a peer firm's analyst coverage due to a broker closure/merger on voluntary disclosure. A firm is included in the treated sample if the firm shares at least one blockholder with at least one same-industry Affected Peer (i.e., firm that experiences a loss in analyst coverage), where the treatment firm did not have a loss in analyst coverage. A firm is included in the control group if the firm does not share any blockholder with any same-industry Affected Peer, where the control firm did not have a loss in analyst coverage. Treatment Closure is an indicator variable that equals one for treated firms and zero for control firms. Pre [-1] Closure and Post Closure are indicator variables that equal one for the year that ends one month before the merger announcement and the year that starts one month after the broker closure/merger. All specifications include broker closure/merger event $\times$ affected peer $\times$ firm and year fixed effects. Standard errors are clustered at the broker closure/merger level. ***,*** indicate statistical significance at the $10 \%, 5 \%$, and $1 \%$ levels, respectively, using a two-tailed t-test.

\begin{tabular}{lccccc}
\hline & $(1)$ & $(2)$ & $(3)$ & $(4)$ & $(5)$ \\
Dependent Variable: & Guide & $\begin{array}{c}\text { Earnings } \\
\text { Forecast Freq }\end{array}$ & $\begin{array}{c}\text { Capex } \\
\text { Guide }\end{array}$ & $\begin{array}{c}\text { Capex } \\
\text { Forecast Freq }\end{array}$ & \%Redaction \\
\hline \hline Treatment Closure $\times$ Pre [-1] Closure & -0.005 & 0.003 & 0.015 & 0.016 & -0.003 \\
Treatment Closure $\times$ Post Closure & $(-0.661)$ & $(0.257)$ & $(1.508)$ & $(1.318)$ & $(-0.911)$ \\
Treatment Closure & 0.005 & $0.024^{*}$ & $0.027^{* * *}$ & $0.041^{* * *}$ & -0.004 \\
& $(0.513)$ & $(1.954)$ & $(2.861)$ & $(3.581)$ & $(-0.756)$ \\
Pre [-1] Closure & $0.009^{*}$ & 0.001 & $-0.011^{* *}$ & $-0.013^{* *}$ & 0.002 \\
& $(1.826)$ & $(0.169)$ & $(-2.098)$ & $(-2.079)$ & $(0.884)$ \\
Post Closure & -0.015 & -0.013 & 0.004 & 0.004 & -0.000 \\
& $(-0.888)$ & $(-0.571)$ & $(0.711)$ & $(0.610)$ & $(-0.146)$ \\
Institutional Ownership & 0.009 & 0.039 & 0.003 & 0.005 & -0.003 \\
Blockholder Ownership & $(0.394)$ & $(1.228)$ & $(0.411)$ & $(0.407)$ & $(-0.785)$ \\
& 0.101 & $0.155^{*}$ & 0.002 & -0.023 & -0.010 \\
& $(1.435)$ & $(1.919)$ & $(0.114)$ & $(-0.851)$ & $(-0.721)$ \\
No. of Observations & $-0.163 * *$ & $-0.269^{* * *}$ & -0.002 & 0.018 & 0.009 \\
Adj. R-Squared & $(-2.479)$ & $(-3.801)$ & $(-0.121)$ & $(0.860)$ & $(0.681)$ \\
Firm $\times$ Closure $\times$ Affected Peer & 419,566 & 419,566 & 419,566 & 419,566 & 581,742 \\
Indicators & 0.566 & 0.676 & 0.526 & 0.546 & 0.372 \\
Year Indicators & Yes & Yes & Yes & Yes & Yes \\
Other controls from Tables 4 to 6 & Yes & Yes & Yes & Yes & Yes \\
SE Clustered by Closure & Yes & Yes & Yes & Yes & Yes \\
\hline \hline
\end{tabular}


Table 9

Difference-in-Differences analyses of the effect of common ownership on disclosure

This table reports difference-in-difference results examining the effects of increased common blockholdings due to institution mergers on voluntary disclosure. A firm is included in the treated sample if (i) it is blockheld by one, but not both, of merging institution in the quarter before the announcement of the merger and (ii) the other merging institutions blockholds at least one of the same-industry firms in the quarter before the announcement of the merger. A firm is included in the control group if (i) it is blockheld by the same institution that holds a treated firm and (ii) none of its same-industry peers are blockheld by the other merging institution in the quarter immediately before the announcement of the merger. Treatment is an indicator variable that equals one for treated firms and zero for control firms. Pre [-1] and Post are indicator variables that equal one for the fiscal year immediately before the merger announcement and the fiscal year immediately after the merger completion. All specifications include firm $\times$ merger and year fixed effects. Standard errors are clustered at the year and firm level. ${ }^{*, * *, * * *}$ indicate statistical significance at the $10 \%, 5 \%$, and $1 \%$ levels, respectively, using a two-tailed $t$-test.

\begin{tabular}{|c|c|c|c|c|c|}
\hline Dependent Variable: & $\begin{array}{c}\text { (1) } \\
\text { Earnings } \\
\text { Guide }\end{array}$ & $\begin{array}{c}(2) \\
\text { Earnings } \\
\text { Forecast Freq }\end{array}$ & $\begin{array}{l}\text { (3) } \\
\text { Capex } \\
\text { Guide }\end{array}$ & $\begin{array}{c}\text { (4) } \\
\text { Capex } \\
\text { Forecast Freq }\end{array}$ & $\begin{array}{c}(5) \\
\text { \%Redaction }\end{array}$ \\
\hline Treatment $\times$ Pre $[-1]$ & $\begin{array}{c}0.022 \\
(0.969)\end{array}$ & $\begin{array}{c}0.018 \\
(0.517)\end{array}$ & $\begin{array}{c}0.012 \\
(0.463)\end{array}$ & $\begin{array}{c}0.049 \\
(1.020)\end{array}$ & $\begin{array}{c}0.009 \\
(0.772)\end{array}$ \\
\hline Treatment $\times$ Post & $\begin{array}{l}0.055^{* *} \\
(2.078)\end{array}$ & $\begin{array}{c}0.033 \\
(0.534)\end{array}$ & $\begin{array}{l}0.069^{*} \\
(1.739)\end{array}$ & $\begin{array}{l}0.116^{*} \\
(1.832)\end{array}$ & $\begin{array}{c}0.001 \\
(0.151)\end{array}$ \\
\hline $\operatorname{Pre}[-1]$ & $\begin{array}{c}-0.002 \\
(-0.283)\end{array}$ & $\begin{array}{l}-0.014^{*} \\
(-2.016)\end{array}$ & $\begin{array}{c}0.000 \\
(0.004)\end{array}$ & $\begin{array}{l}-0.008 \\
(-0.746)\end{array}$ & $\begin{array}{c}0.005 \\
(1.369)\end{array}$ \\
\hline Post & $\begin{array}{c}-0.046 \\
(-0.873)\end{array}$ & $\begin{array}{c}-0.107 \\
(-1.217)\end{array}$ & $\begin{array}{l}-0.087^{*} \\
(-2.115)\end{array}$ & $\begin{array}{l}-0.119^{*} \\
(-1.811)\end{array}$ & $\begin{array}{c}0.015 \\
(0.926)\end{array}$ \\
\hline Common Dummy DiffInd & $\begin{array}{c}-0.002 \\
(-0.048)\end{array}$ & $\begin{array}{c}-0.047 \\
(-0.952)\end{array}$ & $\begin{array}{l}-0.066^{*} \\
(-1.908)\end{array}$ & $\begin{array}{c}-0.121 * * \\
(-2.875)\end{array}$ & $\begin{array}{c}-0.012 \\
(-1.512)\end{array}$ \\
\hline Institutional Ownership & $\begin{array}{c}0.039 \\
(0.437)\end{array}$ & $\begin{array}{c}0.195 \\
(1.418)\end{array}$ & $\begin{array}{c}0.069 \\
(0.804)\end{array}$ & $\begin{array}{c}0.093 \\
(1.023)\end{array}$ & $\begin{array}{c}0.018 \\
(0.704)\end{array}$ \\
\hline Blockholder Ownership & $\begin{array}{c}-0.054 \\
(-0.767)\end{array}$ & $\begin{array}{c}-0.251^{* *} \\
(-2.266)\end{array}$ & $\begin{array}{c}-0.029 \\
(-0.288)\end{array}$ & $\begin{array}{c}-0.194 \\
(-1.568)\end{array}$ & $\begin{array}{c}0.010 \\
(0.446)\end{array}$ \\
\hline No. of Observations & 5,896 & 5,896 & 5,896 & 5,896 & 7,080 \\
\hline Adj. R-Squared & 0.701 & 0.741 & 0.591 & 0.654 & 0.337 \\
\hline Firm $\times$ Merger Indicators & Yes & Yes & Yes & Yes & Yes \\
\hline Year Indicators & Yes & Yes & Yes & Yes & Yes \\
\hline Other controls from Tables 4 to 6 & Yes & Yes & Yes & Yes & Yes \\
\hline SE Clustered by Firm and Year & Yes & Yes & Yes & Yes & Yes \\
\hline
\end{tabular}




\section{Table 10}

Blockholder fixed effects

This table presents the results from regressing voluntary disclosure on lagged common ownership and other determinants of disclosure. Panels A, B, C, D, and E report results when Earnings Guide, Earnings Forecast Freq, Capex Guide, Capex Forecast Freq, and \%Redaction are proxies for voluntary disclosure, respectively. All continuous variables are winsorized at the 1\% and 99\% levels and are defined in the Variable Appendix. All specifications include firm, industry $\times$ year, and blockholder fixed effects. Standard errors are clustered at the year and firm level. ${ }^{* * *, * * *}$ indicate statistical significance at the $10 \%, 5 \%$, and $1 \%$ levels, respectively, using a two-tailed $t$-test.

Panel A: Using an indicator variable for earnings forecasts as the proxy for voluntary disclosure
(1)
(2)
(3)

(4)

\begin{tabular}{|c|c|c|c|c|c|}
\hline Dependent Variable: & $\begin{array}{c}\text { Pr. } \\
\text { Sign }\end{array}$ & & Earn & uide & \\
\hline Common Dummy & + & $\begin{array}{l}0.017 * \\
(1.970)\end{array}$ & & & \\
\hline No. Common Firms & + & & $\begin{array}{c}0.013 * * \\
(2.546)\end{array}$ & & \\
\hline MV Common Firms & + & & & $\begin{array}{c}0.005 * * \\
(2.522)\end{array}$ & \\
\hline No. Common Investors & + & & & & $\begin{array}{c}0.024 * * \\
(2.240)\end{array}$ \\
\hline No. of Observations & & 54,541 & 54,541 & 54,541 & 54,541 \\
\hline Adj. R-Squared & & 0.620 & 0.620 & 0.620 & 0.620 \\
\hline Firm \& Year $\times$ Industry Indicators & & Yes & Yes & Yes & Yes \\
\hline Blockholder Indicators & & Yes & Yes & Yes & Yes \\
\hline Control Variables Included & & Yes & Yes & Yes & Yes \\
\hline SE Clustered by Firm and Year & & Yes & Yes & Yes & Yes \\
\hline
\end{tabular}

Panel B: Using earnings forecast frequency as the proxy for voluntary disclosure
(1)
(2)
(3)

(4)

Dependent Variable:

\begin{tabular}{ll}
\hline \hline Common Dummy & + \\
No. Common Firms & + \\
MV Common Firms & +
\end{tabular}

No. Common Investors

No. of Observations

Adj. R-Squared

Firm \& Year $\times$ Industry Indicators

Blockholder Indicators

Control Variables Included

SE Clustered by Firm and Year
Pr.

Sign

Earnings Forecast Freq

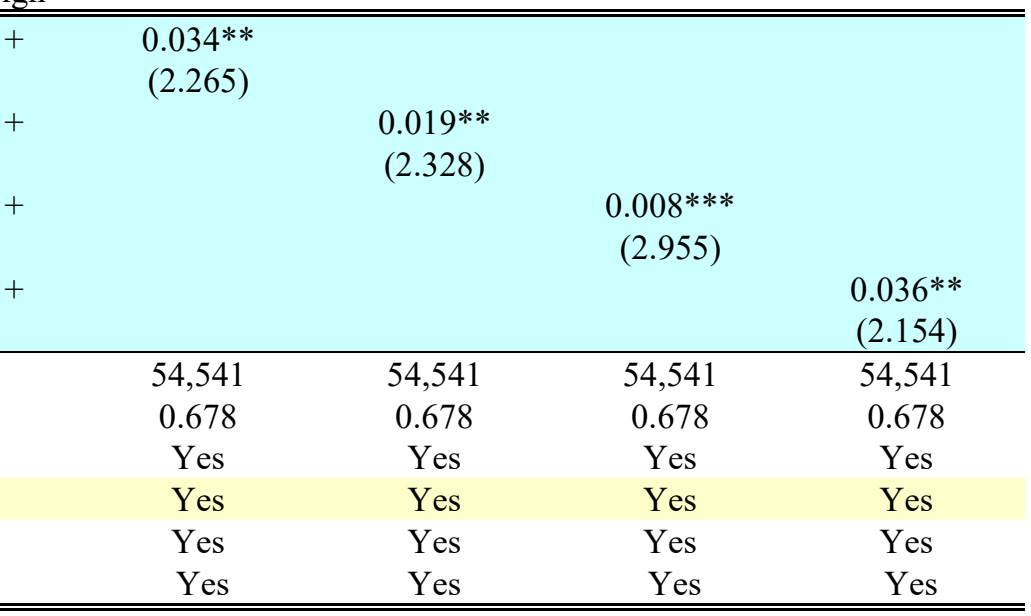


Table 10 (continued)

Panel C: Using an indicator variable for capex forecasts as the proxy for voluntary disclosure

\begin{tabular}{|c|c|c|c|c|c|}
\hline \multirow[b]{2}{*}{ Dependent Variable: } & \multirow[b]{2}{*}{$\begin{array}{l}\text { Pr. } \\
\text { Sign }\end{array}$} & (1) & (2) & (3) & (4) \\
\hline & & \multicolumn{4}{|c|}{ Capex Guide } \\
\hline Common Dummy & + & $\begin{array}{c}0.023 \\
(1.262)\end{array}$ & & & \\
\hline No. Common Firms & + & & $\begin{array}{c}0.011 * * * \\
(3.066)\end{array}$ & & \\
\hline MV Common Firms & + & & & $\begin{array}{c}0.005^{* *} \\
(2.298)\end{array}$ & \\
\hline No. Common Investors & + & & & & $\begin{array}{c}0.025 \\
(0.370)\end{array}$ \\
\hline No. of Observations & & 54,541 & 54,541 & 54,541 & 54,541 \\
\hline Adj. R-Squared & & 0.596 & 0.596 & 0.596 & 0.596 \\
\hline Firm \& Year $\times$ Industry Indicators & & Yes & Yes & Yes & Yes \\
\hline Blockholder Indicators & & Yes & Yes & Yes & Yes \\
\hline Control Variables Included & & Yes & Yes & Yes & Yes \\
\hline SE Clustered by Firm and Year & & Yes & Yes & Yes & Yes \\
\hline
\end{tabular}

Panel D: Using capex forecast frequency as the proxy for voluntary disclosure

(1) (2) (3)

(4)

\begin{tabular}{|c|c|c|c|c|c|}
\hline Dependent Variable: & $\begin{array}{l}\text { Pr. } \\
\text { Sign }\end{array}$ & . & Capex & st Freq & \\
\hline Common Dummy & + & $\begin{array}{l}0.028 * \\
(2.100)\end{array}$ & & & \\
\hline No. Common Firms & + & & $\begin{array}{c}0.014 * * \\
(2.428)\end{array}$ & & \\
\hline MV Common Firms & + & & & $\begin{array}{c}0.007 * * \\
(2.531)\end{array}$ & \\
\hline No. Common Investors & + & & & & $\begin{array}{c}0.034 * * \\
(2.719)\end{array}$ \\
\hline No. of Observations & & 54,541 & 54,541 & 54,541 & 54,541 \\
\hline Adj. R-Squared & & 0.649 & 0.649 & 0.649 & 0.649 \\
\hline Firm \& Year $\times$ Industry Indicators & & Yes & Yes & Yes & Yes \\
\hline Blockholder Indicators & & Yes & Yes & Yes & Yes \\
\hline Control Variables Included & & Yes & Yes & Yes & Yes \\
\hline SE Clustered by Firm and Year & & Yes & Yes & Yes & Yes \\
\hline
\end{tabular}

Panel E: Using redactions from material contracts filed with the SEC as the proxy for voluntary disclosure

\begin{tabular}{|c|c|c|c|c|c|}
\hline \multirow[b]{2}{*}{ Dependent Variable: } & \multirow[b]{2}{*}{$\begin{array}{c}\text { Pr. } \\
\text { Sign }\end{array}$} & $(1)$ & $(2)$ & (3) & (4) \\
\hline & & \multicolumn{4}{|c|}{$\%$ Redaction } \\
\hline Common Dummy & -/? & $\begin{array}{c}-0.002 \\
(-0.480)\end{array}$ & & & \\
\hline No. Common Firms & $-/ ?$ & & $\begin{array}{c}0.001 \\
(0.481)\end{array}$ & & \\
\hline MV Common Firms & $-/ ?$ & & & $\begin{array}{c}-0.000 \\
(-0.686)\end{array}$ & \\
\hline No. Common Investors & $-/ ?$ & & & & $\begin{array}{c}-0.002 \\
(-0.382)\end{array}$ \\
\hline No. of Observations & & 66,455 & 66,455 & 66,455 & 66,455 \\
\hline Adj. R-Squared & & 0.310 & 0.310 & 0.310 & 0.310 \\
\hline Firm \& Year $\times$ Industry Indicators & & Yes & Yes & Yes & Yes \\
\hline Blockholder Indicators & & Yes & Yes & Yes & Yes \\
\hline Control Variables Included & & Yes & Yes & Yes & Yes \\
\hline SE Clustered by Firm and Year & & Yes & Yes & Yes & Yes \\
\hline
\end{tabular}




\section{Table 11}

Effect of common ownership on stock liquidity

This table presents the results from regressing stock liquidity on lagged common ownership and other determinants of liquidity. In Panel A, the proxy for liquidity is BidAsk, which is the effective bid-ask spreads of quoted prices. In Panel B, the proxy for liquidity is Amihud, which is a proxy for price impact of trades based on Amihud (2002). All continuous variables are winsorized at the 1\% and 99\% levels and are defined in the Variable Appendix. All specifications include firm and industry $\times$ year fixed effects. Standard errors are clustered at the year and firm level. ${ }^{*, * *, * * *}$ indicate statistical significance at the $10 \%, 5 \%$, and $1 \%$ levels, respectively, using a two-tailed $t$-test.

Panel A: Using Bid-Ask spreads as the proxy for liquidity

(1) (2) BidAsk

\begin{tabular}{|c|c|c|c|c|c|}
\hline Dependent Variable: & Pr. Sign & & & & \\
\hline Common Dummy & - & $\begin{array}{c}-0.350 * * \\
(-2.507)\end{array}$ & & & \\
\hline No. Common Firms & - & & $\begin{array}{l}-0.165^{*} \\
(-1.682)\end{array}$ & & \\
\hline MV Common Firms & - & & & $\begin{array}{l}-0.052 * \\
(-1.923)\end{array}$ & \\
\hline No. Common Investors & - & & & & $\begin{array}{c}-0.599 * * * \\
(-3.123)\end{array}$ \\
\hline Institutional Ownership & & $\begin{array}{c}-2.610 * * * \\
(-3.931)\end{array}$ & $\begin{array}{c}-2.309 * * * \\
(-3.512)\end{array}$ & $\begin{array}{c}-2.333 * * * \\
(-3.479)\end{array}$ & $\begin{array}{c}-2.681 * * * \\
(-4.175)\end{array}$ \\
\hline Blockholder Ownership & & $\begin{array}{c}2.424 * * \\
(2.736)\end{array}$ & $\begin{array}{c}2.549 * * \\
(2.915)\end{array}$ & $\begin{array}{c}2.473 * * \\
(2.821)\end{array}$ & $\begin{array}{c}2.281 * * \\
(2.575)\end{array}$ \\
\hline Common Ownership DiffInd & & $\begin{array}{l}0.470 * \\
(1.892)\end{array}$ & $\begin{array}{c}0.003 \\
(0.076)\end{array}$ & $\begin{array}{c}0.008 \\
(0.332)\end{array}$ & $\begin{array}{c}0.545 * * \\
(2.480)\end{array}$ \\
\hline Analysts & & $\begin{array}{c}-0.458 * * \\
(-2.639)\end{array}$ & $\begin{array}{c}-0.454 * * \\
(-2.608)\end{array}$ & $\begin{array}{c}-0.451 * * \\
(-2.584)\end{array}$ & $\begin{array}{c}-0.454 * * \\
(-2.614)\end{array}$ \\
\hline Assets & & $\begin{array}{c}-2.103 * * * \\
(-8.661)\end{array}$ & $\begin{array}{c}-2.098 * * * \\
(-8.571)\end{array}$ & $\begin{array}{c}-2.102 * * * \\
(-8.583)\end{array}$ & $\begin{array}{c}-2.099 * * * \\
(-8.672)\end{array}$ \\
\hline Stdev. Return & & $\begin{array}{c}4.134 * * * \\
(8.702)\end{array}$ & $\begin{array}{c}4.132 * * * \\
(8.672)\end{array}$ & $\begin{array}{c}4.137 * * * \\
(8.683)\end{array}$ & $\begin{array}{c}4.136 * * * \\
(8.701)\end{array}$ \\
\hline Price & & $\begin{array}{c}6.397 * * * \\
(24.266)\end{array}$ & $\begin{array}{c}6.376^{* * *} \\
(24.227)\end{array}$ & $\begin{array}{c}6.382 * * * \\
(24.151)\end{array}$ & $\begin{array}{c}6.409 * * * \\
(24.152)\end{array}$ \\
\hline Turnover & & $\begin{array}{c}-3.121 * * * \\
(-7.592)\end{array}$ & $\begin{array}{c}-3.126^{* * *} \\
(-7.575)\end{array}$ & $\begin{array}{c}-3.126 * * * \\
(-7.591)\end{array}$ & $\begin{array}{c}-3.121 * * * \\
(-7.586)\end{array}$ \\
\hline No. of Observations & & 36,905 & 36,905 & 36,905 & 36,905 \\
\hline Adj. R-Squared & & 0.804 & 0.804 & 0.804 & 0.804 \\
\hline Firm \& Year $\times$ Industry Indicators & & Yes & Yes & Yes & Yes \\
\hline SE Clustered by Firm and Year & & Yes & Yes & Yes & Yes \\
\hline
\end{tabular}




\section{Table 11 (continued)}

Panel B: Using the Amihud (2002) measure of price impact of trades as the proxy for liquidity

(1)

Pr. Sign

Dependent Variable:

Common Dummy

No. Common Firms

MV Common Firms

No. Common Investors

Institutional Ownership

Blockholder Ownership

Common Ownership DiffInd

Analysts

Assets

Stdev. Return

Price

Turnover

No. of Observations

Adj. R-Squared

Firm \& Year $\times$ Industry Indicators

SE Clustered by Firm and Year

$-$

$-0.024 *$

$(-1.796)$

$-$
(2)

(3) Amihud
(4)
$-0.024 * *$

$(-2.204)$

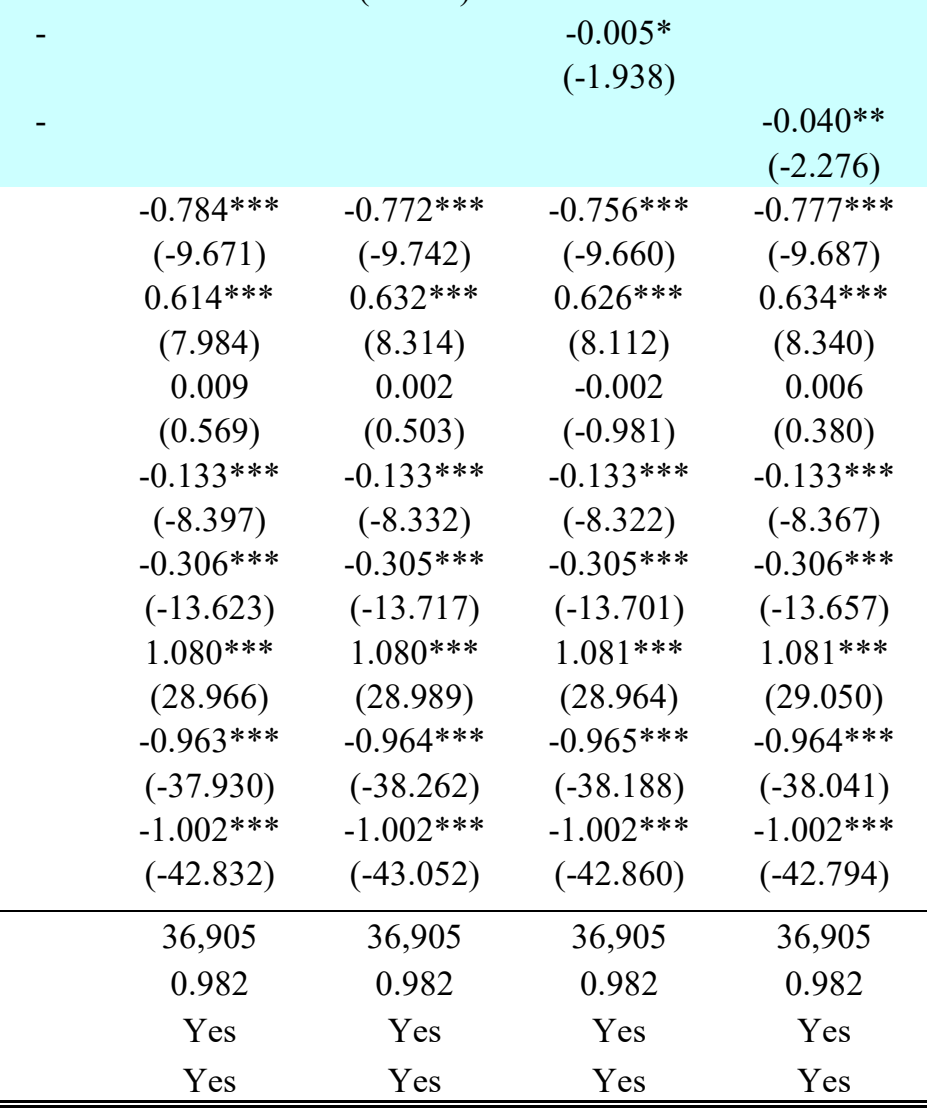

